\title{
Article \\ Co-Benefits Analysis of Buildings Based on Different Renewal Strategies: The Emergy-Lca Approach
}

\author{
Wenjing Cui ${ }^{1}$, Jingke Hong ${ }^{1}$, Guiwen Liu ${ }^{1, *}$, Kaijian Li ${ }^{1} \oplus$, Yuanyuan Huang ${ }^{1}$ and Lin Zhang ${ }^{2} \mathbb{D}$ \\ 1 School of Management Science and Real Estate, Chongqing University, Chongqing 400044, China; \\ 20170301004@cqu.edu.cn (W.C.); hongjingke@cqu.edu.cn (J.H.); likaijian@cqu.edu.cn (K.L.); \\ 20170301015@cqu.edu.cn (Y.H.) \\ 2 School of Management Engineering, Shandong Jianzhu University, Jinan 250101, China; \\ zhanglin2007@sdjzu.edu.cn \\ * Correspondence: gwliu@cqu.edu.cn; Tel.: +86-23-6512-0976
}

Citation: Cui, W.; Hong, J.; Liu, G.; Li, K.; Huang, Y.; Zhang, L. Co-Benefits Analysis of Buildings Based on Different Renewal Strategies: The Emergy-Lca Approach. Int. J. Environ. Res. Public Health 2021, 18, 592. https:// doi.org/10.3390/ijerph18020592

Received: 28 October 2020 Accepted: 4 January 2021 Published: 12 January 2021

Publisher's Note: MDPI stays neutral with regard to jurisdictional clai$\mathrm{ms}$ in published maps and institutional affiliations.

Copyright: (C) 2021 by the authors. Licensee MDPI, Basel, Switzerland. This article is an open access article distributed under the terms and conditions of the Creative Commons Attribution (CC BY) license (https:// creativecommons.org/licenses/by/ $4.0 /)$

\begin{abstract}
Many cities have encountered challenges associated with rapid urban development, population growth and aging, in which urban renewal has become a promising option. Different renewal strategies, such as redevelopment, refurbishment and conservation, not only contributes to quality improvement and energy consumption reduction of dilapidated urban area, but also to greenhouse gas (GHG) emissions mitigation. Such integrated benefits are often termed as co-benefits. However, choosing the most co-benefits strategy to adopt requires a holistic understanding of social-economic and environmental aspects, which has been less reported in the existing literature. Under such circumstance, this article aims to shed light on the co-benefits of different renewal strategies by adopting the Emergy-Life cycle assessment method. Then, the method is applied to one case study of the refurbishment of an educational building located in Chongqing, China. Resource allocation, $\mathrm{CO}_{2}$ emissions and emergy-based indicators are calculated to assess the co-benefits during a 60-year research period, to compare the impacts of the complete demolition followed by a new one (rebuilding strategy) and the refurbishing of the existing building (refurbishment strategy). The case study shows that the annual emergy in the O\&M phase of rebuilding strategy and refurbishment strategy were lower than existing building. Rebuilding and refurbishment strategies released approximately $59.1 \%$ and $80.6 \%$, respectively, of the total $\mathrm{CO}_{2}$ emissions that would be produced by the existing building. The results reveal that substantial environmental benefits can be obtained in both the refurbishment and rebuilding strategies. On the other hand, it can be concluded that the emergy yield ratio (EYR) for the rebuilding strategy is higher than refurbishment strategy, which demonstrate the better performance of refurbishment considering that less resources are required to generate greater benefits. In addition, the value of environmental loading ratio (ELR) and emergy sustainability index (ESI) also suggests that the refurbishment strategy performs better from the perspective of the environment. Thereby, the refurbishment strategy is more suitable than the rebuilding strategy. Findings from this study can be useful to urban planners and decision-makers in choosing the most suitable strategy to improve the quality of existing buildings.
\end{abstract}

Keywords: urban renewal; co-benefits; emergy analysis; life cycle assessment (lca); refurbishment strategy; rebuilding strategy

\section{Introduction}

Most cities worldwide are exposed to social-economic and environmental challenges caused by rapid industrialization, population growth and urbanization [1]. These challenges include urban dilapidation, economic decline, unreasonable utilization of land and environmental pollution [2-4]. Urban renewal, as a process to achieve the sustainable development in terms of economy, society and environment [5-7], is an ideal approach to resolve urban issues. 
Urban renewal, also known as urban regeneration, offers a chance to improve the physical, social, economic and ecological conditions of decaying urban areas by three strategies: rebuilding, refurbishment and conservation [7]. One of the main strategies of urban renewal is rebuilding, which involves demolishing dilapidated buildings and replacing them with brand-new buildings, as was done in New York, USA, from 1949-1972 [8]. The rebuilding strategy enables eradication of substandard buildings and improves the land use $[9,10]$. Moreover, it can easily incorporate open spaces and community facilities, which gives neighborhoods in the redevelopment sites a positive externality $[10,11]$ and reduces energy consumption [12]. However, rebuilding destroys the social fabric of cities [13] and generates a large amount of construction waste [14].

Refurbishment refers to the rehabilitation of outdated buildings through a series of efforts, to improve quality standards and function [9]. Generally, the main volume of the building was preserved in refurbishment strategy. The refurbishment strategy offers a quicker and less socially disturbing option to improve the building stock quality [10,11]. In addition, the refurbishment strategy enables building energy performance improvement through the integration of energy efficiency and renewable energy measures [15]. However, according to [16], the cost of refurbishment is similar to that of rebuilding.

The third strategy is conservation, also known as preservation or restoration, which is usually performed in heritage buildings [17]. Conservation includes a series of processes to maintain a building and preserve and protect its historical and cultural values [13]. However, most of the old building envelopes have a poor thermal insulation performance [18,19], which requires frequent repair and rehabilitation measures [17].

Although the co-benefits captured in the above three urban renewal strategies is significant, the decision which strategy to adopt is complex and requires the integration of social, economic, and environmental parameters [17]. The process of choosing the appropriate urban renewal strategy has been debated for over a century [20]. However, it remains unclear whether rebuilding, refurbishing or conserving existing buildings is the most suitable option [21]. In this context, the aims of this study are (i) to investigate the co-benefits of different renewal strategies by employing EM-LCA method (combination of emergy and LCA method); (ii) to provide a comparison between refurbishment strategy and rebuilding strategy. Figure 1 illustrates the stages of the research. After the introduction section, the review of the relevant work on the topic is discussed in Section 2. Additionally, the EM-LCA method adopted in this study is presented in Section 3. Then, a detailed case description and three strategies is provided in Section 4. Sections 5 and 6 first focus on the results and discussion of the emergy of the building system and the greenhouse gas (GHG) emissions in every strategy, and the co-benefits of different renewal strategies are then revealed and compared. Finally, certain conclusions are drawn.

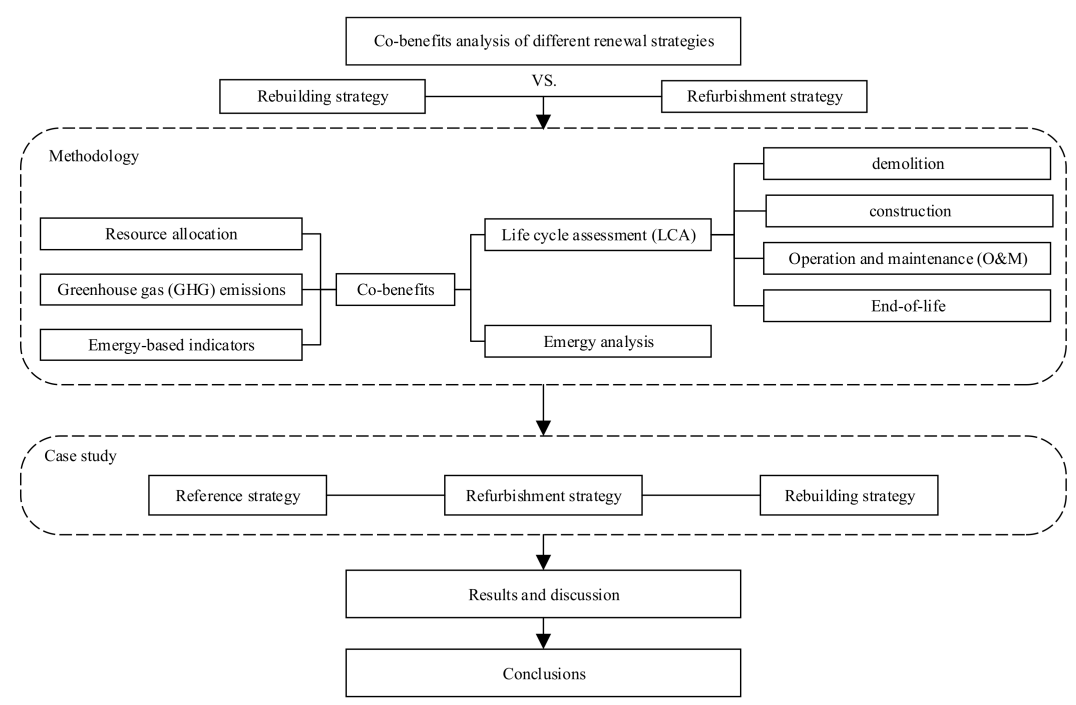

Figure 1. Research framework. 


\section{Review of Relevant Works}

Several recent studies on the comparison between refurbishment strategy and rebuilding strategy were conducted around the world (Table 1). However, the results of this research were polarized. Some researchers argued that refurbishment strategy was better than rebuilding strategy in terms of cost, time, energy performance, $\mathrm{CO}_{2}$ emissions and other environmental indicators. A recent study on energy-saving measures was conducted by Gaspar and Santos, the results revealed that the rebuilding strategy consumed more embodied energy than the refurbishment strategy [16]. Weiler et al. calculated the embodied energy, the embodied greenhouse gases (GHGs), the energy required and the GHGs emitted during the life cycle of an individual building [22]. Accordingly, Weiler suggested that refurbishing is better than rebuilding. Hasik et al. conducted a comparative between refurbishment and new construction by a whole-building life cycle assessment, which showed that $53-75 \%$ reductions when the refurbishment was compared to rebuilding strategy in terms of acidification potential, eutrophication potential, global warming potential, ozone depletion potential, smog formation potential and non-renewable energy demand [23]. For materials and waste, the environmental impact of refurbishment strategy is better rebuilding strategy [24].

In contrast, some previous comparison studies of refurbishment and rebuilding have other different opinions. A life cycle performance for 4 refurbishment scenarios and 2 reconstruction scenarios were investigated, the results showed that the rebuilding scenarios appear to be the better choice compared to refurbishment when the total life cycle emissions intensity is considered [25]. The same results were also gained by Rønning et al., which investigated a Norwegian bank through a hybrid LCA approach [26]. In addition, for the cost, Ferreira, Pinheiro and Brito suggested the refurbishment strategy was less competitive than rebuilding strategy [27].

Based on the aforementioned review, the results of previous studies suggested that urban renewal have some co-benefits over existing buildings, such as the improvement of building quality and function, the reduction of energy consumption and the improvement of environment. However, several research gaps are identified from the current studies. The results of previous researches about whether rebuilding or refurbishing existing buildings is the better option remains unclear [21]. As Table 1 shows, these studies mainly focused on the residential building in European countries, few studies have been carried out to investigated the office building. Energy and cost were adopted in most studies as the mainly criteria to make comparison, which neglect other aspects. Moreover, numerous studies adopted the life cycle assessment (LCA) method to assess the energy consumption of different renewal strategy. LCA method only studies the environmental impacts of products or processes but neglects the impacts of other aspects, such as economic effects [28]. The decision which strategy to adopt is complex and requires a comprehensive tool to integrate social, economic, environmental, and political-institutional parameters [17].

Emergy (Em) is an environmental policy tool for evaluating the quality of resources based on the dynamics of complex systems [33]. Odum defined emergy as the total amount of one kind of available energy (exergy) that is directly or indirectly used in transformations to generate a given product or support a given service [34]. Em assesses the system performance by quantifying the emergy value of different kinds of resources, such as renewable and nonrenewable resources, labor/services, gas emissions, and liquid and solid wastes [35]. Accordingly, with Em, it is possible to develop a link between economic and ecological systems [36-38] and allows the direct comparison of different products and services $[39,40]$. In addition, the Em method can not only investigate the social-economic and environmental impacts of a system [41] but can also analyze the resources consumed to support labor and services, which is often not considered in the process of LCA [42]. The combination of Emergy and LCA (EM-LCA) is a more comprehensive sustainability assessment tool for complex systems $[28,43]$. 
Table 1. Recent studies on comparison of rebuilding and refurbishment.

\begin{tabular}{|c|c|c|c|c|c|}
\hline $\begin{array}{l}\text { Literature } \\
\text { Source }\end{array}$ & Country & $\begin{array}{l}\text { Building } \\
\text { Type }\end{array}$ & Method & $\begin{array}{l}\text { Measurement } \\
\text { Criteria }\end{array}$ & Main Conclusions \\
\hline $\begin{array}{l}\text { La Fleur, } \\
\text { Rohdin [29] }\end{array}$ & Sweden & Residential & $\begin{array}{l}\text { Life cycle } \\
\text { assessment } \\
\text { (LCA) }\end{array}$ & $\begin{array}{l}\text { Life cycle cost } \\
\quad(\text { LCC) }\end{array}$ & $\begin{array}{c}\text { The cost of the new building is higher compared } \\
\text { to energy renovation. }\end{array}$ \\
\hline $\begin{array}{l}\text { Gaspar and } \\
\text { Santos [16] }\end{array}$ & Portugal & Residential & $\begin{array}{l}\text { cradle-to- } \\
\text { gate }\end{array}$ & $\begin{array}{l}\text { Energy } \\
\text { Weigh }\end{array}$ & $\begin{array}{c}\text { Refurbishment was a more sustainable strategy } \\
\text { than rebuilding. }\end{array}$ \\
\hline $\begin{array}{c}\text { Weiler, } \\
\text { Harter [22] }\end{array}$ & Germany & Residential & LCA & Energy & $\begin{array}{l}\text { It is better to refurbish an existing building than } \\
\text { to demolish it and reconstruct. }\end{array}$ \\
\hline $\begin{array}{l}\text { Morelli, } \\
\text { Harrestrup } \\
\text { [30] }\end{array}$ & Denmark & Residential & $\begin{array}{l}\text { Two-fold } \\
\text { evaluation }\end{array}$ & $\begin{array}{l}\text { Cost of } \\
\text { conserved } \\
\text { energy }\end{array}$ & $\begin{array}{c}\text { Renovating the building will be an economically } \\
\text { sensible solution as compared to demolishing } \\
\text { and erecting a new one. }\end{array}$ \\
\hline $\begin{array}{l}\text { Marique } \\
\text { and Rossi } \\
\text { [21] }\end{array}$ & Brussels & Office & LCA & Energy & $\begin{array}{l}\text { The retrofitting of the building is significantly } \\
\text { less harmful than its complete } \\
\text { demolition/reconstruction. }\end{array}$ \\
\hline $\begin{array}{l}\text { Ferreira, } \\
\text { Duarte } \\
\text { Pinheiro } \\
\text { [27] }\end{array}$ & Portugal & Palace & $\begin{array}{l}\text { cradle-to- } \\
\text { gate }\end{array}$ & $\begin{array}{l}\text { Energy } \\
\text { Cost }\end{array}$ & $\begin{array}{l}\text { Refurbishment was environmentally more } \\
\text { positive than the new equivalent construction. } \\
\text { For cost, refurbishment was less competitive } \\
\text { than demolition followed by a new equivalent } \\
\text { construction. }\end{array}$ \\
\hline $\begin{array}{l}\text { Rønning, } \\
\text { Vold } \\
\text { [26] }\end{array}$ & Norway & $\begin{array}{l}\text { Norwegian } \\
\text { Bank }\end{array}$ & LCA & Energy & $\begin{array}{l}\text { From a climate point of view the most } \\
\text { favourable strategy was to replace the existing } \\
\text { construction and build a new one. }\end{array}$ \\
\hline $\begin{array}{l}\text { Elmezaini } \\
{[31]}\end{array}$ & Gaza & $\begin{array}{l}\text { Al-Amin } \\
\text { Mosque }\end{array}$ & & $\begin{array}{l}\text { Time } \\
\text { Cost }\end{array}$ & $\begin{array}{l}\text { A cautious repairing program was successfully } \\
\text { adopted which saved time and cost. }\end{array}$ \\
\hline $\begin{array}{l}\text { Itard and } \\
\text { Klunder } \\
\text { [32] }\end{array}$ & Netherlands & Residential & LCA & $\begin{array}{l}\text { Material } \\
\text { Energy } \\
\text { Water use } \\
\text { Demolition } \\
\text { waste }\end{array}$ & $\begin{array}{l}\text { The transformation of the existing housing stock } \\
\text { is found to be a much more environmentally } \\
\text { efficient way to achieve the same result than are } \\
\text { demolition and rebuilding. }\end{array}$ \\
\hline $\begin{array}{l}\text { Feng, } \\
\text { Liyanage } \\
\text { [25] }\end{array}$ & Canada & Residential & $\begin{array}{l}\text { LCA+ } \\
\text { Building in- } \\
\text { formation } \\
\text { modelling } \\
\quad(\text { BIM })\end{array}$ & Energy & $\begin{array}{l}\text { Renovations lead to much lower embodied } \\
\text { emissions compared to reconstruction. } \\
\text { When the total life cycle emissions intensity is } \\
\text { considered, the reconstruction options also } \\
\text { appear to be the better choice compared to } \\
\text { renovations at the full 50-year project assessment } \\
\text { period. }\end{array}$ \\
\hline
\end{tabular}

Measures to mitigate the climate change and environmental pollution can bring some unintentionally positive benefits, as called co-benefits [44]. A growing number of studies having discussed the co-benefits of climate change policy at different countries, particularly China, India and Bangladesh [45-48]. The co-benefits of air quality management plan and GHG emissions reduction strategies in the Seoul metropolitan area and New Zealand were evaluated by some models $[49,50]$. Dong et al. studied the $\mathrm{CO}_{2}$ emissions and air pollutants emissions in China, and the reduction cost and co-benefits effect [51]. The building environment interventions will yield the co-benefits of mitigating climate change and promoting public health [52]. Certified green building substantially generate the co-benefits to public health, which were estimated in the six countries (the United States, China, India, Brazil, Germany and Turkey) [53]. Co-benefits to public health, such as improving the interface between humans and wildlife, reducing the risk of waterborne disease, flood-related morbidity and mortality, and psychological harm, were evaluated [54]. Furthermore, the GHG emissions co-benefits associated with water, waste and transportation usage in LEED building were also investigated in California [55]. As for the existing building, co-benefits of the residents, housing association and society in general, GHG emissions and energy consumption can be achieved after implementing retrofit technological measures [56-58]. The co-benefits of residential buildings in terms of the energy savings, costs and other additional benefits of renovation scenarios were investigated to support decision mak- 
ing $[59,60]$. However, few studies have been conducted relating the co-benefits of different renewal strategies with the whole life cycle approach.

\section{Method}

\subsection{EM-LCA Approach}

In this study, the EM-LCA approach was applied to quantify the co-benefits of the different renewal strategies. This approach aims to offer a same quantitative framework among different resources, energy and human services [36], which is a more comprehensive technique than existing LCA tools [28]. Figure 2 presents an overview of the boundaries of building system and depicts the constituents, resource flows, exchange pathways, and downstream outflows. The system boundary in this research includes both spatial and life cycle process boundaries [61,62]. The spatial boundary is the three-dimensional space of a building, which includes the foundation at the bottom, the highest point and the façade of the building. The lifecycle process boundary includes all the upstream and downstream processes to establish and maintain the functions of a building [63], which contain all processes from the cradle to the grave. The lifecycle process boundary in this study extends from the demolition phase to the end-of-life phase based on the renewal of existing buildings, namely, the demolition phase, construction phase (including the material production phase, transportation phase and on-site phase), O\&M phase and end-of-life phase [63]. This paper does not consider the construction/demolition waste due to the lack of data. The building system is regarded as a thermodynamic engine in which natural, social and economic resources are invested to generate products and maintain the base performance, thereby releasing pollutants to the atmosphere, water bodies and land. Accordingly, the driving energy, materials and interactions, as well as outflows and feedback of the system, are simulated as energy pathways [28].

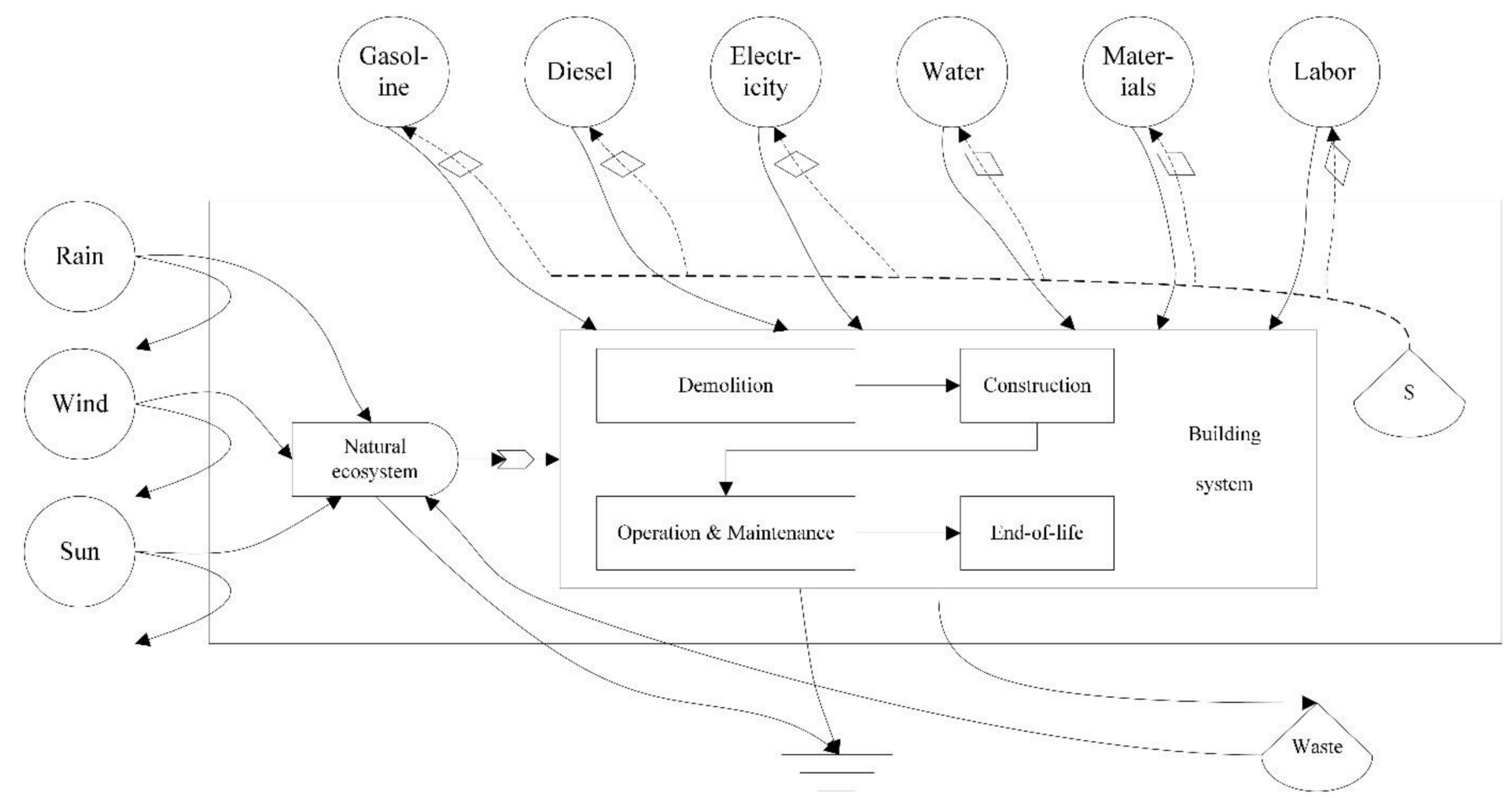

Figure 2. Emergy diagram of the material and energy flows.

\subsection{Resource Allocation}

Seven different types of resources have been identified in the building system input, as shown in the emergy flow diagram in Figure 2. These resources include solar irradiation, materials, electricity, water, diesel fuel, gasoline and human labor. 
(1) Solar irradiation - the input of solar irradiation (Equation (1)) to urban renewal is regarded as a kind of free renewable resource invested in the building system, which can impact the indoor thermal environment of buildings [40,64].

$$
E_{s, c}=S \times I \times(1-a) \times t_{c} \times T_{S}
$$

where $E_{s, c}$ is the solar emergy of the solar irradiation in the construction phase; $S$ is the construction site surface (footprint); I is the annual amount of solar radiation, equal to $3.5 \times 10^{9} \mathrm{~J} / \mathrm{m}^{2}$ [65]; $a$ is the surface albedo, equal to 0.7 in this study; $t_{c}$ is the construction time; and $T_{S}$ is the transformity of solar energy.

(2) Materials-the building materials are the resources invested in the system to construct a building, which mainly occurs in the construction phase $[34,64]$. The emergy of the system inflows can be calculated as follows (Equation (2)):

$$
E_{m}=\sum_{i=1}^{n} M_{i} \times T_{m i}
$$

where $E_{m}$ is the solar emergy of the building materials; $M_{i}$ is the quantity of material $i$; and $T_{m i}$ is the transformity of material $i$.

(3) Electricity-the emergy flow of the electricity (Equation (3)) consumed during the life cycle is calculated as:

$$
E_{e}=W \times T_{e}
$$

where $E_{e}$ is the solar emergy of the electricity required in the building construction, $\mathrm{O} \& \mathrm{M}$ and end-of-life phases; $W$ is the quantity of electricity obtained from the results of energy consumption simulation with EnergyPlus 8.7(developed by Department of Energy and Lawrence Berkeley National Laboratory, Berkeley, California, US); and $T_{e}$ is the transformity of electricity.

(4) Water-the emergy flow of the water (Equations (4) and (5)) used during the building lifetime can be calculated as:

$$
E_{w, c}=V \times \rho_{w} \times G \times T_{w}
$$

where $E_{w, c}$ is the solar emergy of the water consumed in the building demolition, construction and end-of-life phases; $V$ is the required water volume; $\rho_{w}$ is the water density; $G$ is the Gibbs free energy of water, which equals $4.92 \mathrm{~J} / \mathrm{g} \mathrm{[66]}$; and $T_{w}$ is the transformity of water.

$$
E_{w, o}=V_{a} \times N_{n} \times t_{o} \times \rho_{w} \times G \times T_{w}
$$

where $E_{w, o}$ is the solar emergy of the water consumed in the building O\&M phase; $V_{a}$ is the required water volume of one person per day, which equals $20 \mathrm{~L} / \mathrm{d} / \mathrm{p}$ in this study [40]; $N_{n}$ is the number of employees, which equals 200 in this study; and $t_{o}$ is the total number of working days per year, which is assumed to be 300 days in this study.

(5) Diesel fuel-the consumption of diesel fuel mostly occurs during the demolition, construction and end-of-life phases, the emergy of diesel fuel (Equation (6)) can be calculated as:

$$
E_{d}=M_{d} \times c_{d} \times \mathrm{T}_{d}
$$

where $E_{d}$ is the solar emergy of the diesel fuel consumed; $M_{d}$ is the quantity of diesel fuel consumed in the building life cycle; $c_{d}$ is the calorific value of diesel fuel; and $\mathrm{T}_{d}$ is the transformity of diesel fuel.

(6) Gasoline- the solar emergy of gasoline (Equation (7)) is calculated as:

$$
E_{g}=M_{g} \times c_{g} \times \mathrm{T}_{g}
$$

where $E_{g}$ is the solar emergy of gasoline; $M_{g}$ is the quantity of gasoline consumed in the building life cycle; $c_{g}$ is the calorific value of gasoline; and $\mathrm{T}_{g}$ is the transformity of gasoline. 
(7) Human labor-the emergy of human labor (Equation (8)) is mainly required during the building demolition, construction and end-of-life phases. The method for calculating the emergy of labor can be represented as follows [64]:

$$
E_{l}=N_{h} \times N_{n} \times t_{t} \times \mathrm{T}_{l}
$$

where $E_{l}$ is the emergy equivalent of human labor; $N_{h}$ is the number of working hours per day of one employee, which is $8 \mathrm{~h}$ in this study; $N_{n}$ is the number of employees, which equals 10 in this study; $t_{t}$ are the working days required in the life cycle process; and $\mathrm{T}_{l}$ is the transformity of labor.

\subsection{GHG Emissions}

Compared with the material transportation and on-site phases, the $\mathrm{CO}_{2}$ emissions in the raw material manufacturing phase account for $80-90 \%$ of the total emissions [67]. Therefore, the $\mathrm{CO}_{2}$ emissions in the construction phase only include those in the raw material manufacturing phase. The $\mathrm{CO}_{2}$ emissions in the O\&M phase mainly refer to the emissions generated by electricity under the case conditions (Equation (9)), which can be calculated as:

$$
G_{\mathrm{CO}_{2}}=\sum_{i=1}^{n} M_{i} \times E_{\mathrm{CO}_{2}-e q, i}
$$

where $G_{\mathrm{CO}_{2}}$ is the amount of $\mathrm{CO}_{2}$ emissions; $M_{i}$ is the quantity of material $i$; and $E_{\mathrm{CO}_{2}-e q}$ is the emission factor of the different building materials $i$. Table 2 lists the emission factors of the different building materials.

Table 2. Emission factors of the different materials.

\begin{tabular}{ccccc}
\hline No. & Main Building Materials & Unit & Reference & $\mathbf{C O}_{\mathbf{2}}$ Emissions (kg/unit) \\
\hline 1 & Steel & $\mathrm{kg}$ & Peng [68] & 2.208 \\
2 & Cement & $\mathrm{kg}$ & Peng [68] & 0.894 \\
3 & Concrete & $\mathrm{kg}$ & Peng [68] & 0.242 \\
4 & Brick & $\mathrm{kg}$ & Peng [68] & 0.200 \\
5 & Lime & $\mathrm{kg}$ & Peng [68] & 1.200 \\
6 & Gravel & $\mathrm{kg}$ & Peng [68] & 0.002 \\
7 & Glass & $\mathrm{kg}$ & Peng [68] & 1.400 \\
8 & Wood & $\mathrm{kg}$ & Peng [68] & 0.200 \\
9 & Aluminum & $\mathrm{kg}$ & Peng [68] & 1.407 \\
10 & Sand & $\mathrm{kg}$ & Mao, Shen [69] & 0.0069 \\
11 & Diesel & $\mathrm{L}$ & Zhan, Liu [70] & 2.730 \\
12 & Gasoline & $\mathrm{L}$ & Zhan, Liu [70] & 2.260 \\
& & & National & \\
& & & development & \\
13 & Electricity & $\mathrm{kWh}$ & and reform & 0.9929 \\
& & & commission in \\
& & & China (NDRC & \\
& & & [71] \\
\hline
\end{tabular}

\subsection{The Emergy-Based INDICATORS}

The resources input to the building system can be divided into three aspects depending on the source type, i.e., renewable, nonrenewable and purchased resources [72]. The emergy-based indicators to assess the building system performance in this paper are the emergy yield ratio (EYR), environmental loading ratio (ELR) and emergy sustainability index (ESI), as summarized in Table 3. 
Table 3. Emergy indices and description.

\begin{tabular}{cc}
\hline Emergy Indices & Description \\
\hline $\mathrm{R}$ & Renewable resources \\
$\mathrm{N}$ & Nonrenewable resources \\
$\mathrm{F}$ & Emergy feedback \\
$\mathrm{Y}$ & Emergy yield: $\mathrm{N}+\mathrm{R}+\mathrm{F}$ \\
EYR & Emergy yield ratio: $\mathrm{Y} / \mathrm{F}$ \\
$\mathrm{ELR}$ & Environmental loading ratio: $(\mathrm{N}+\mathrm{F}+\mathrm{EL}) / \mathrm{R}$ \\
$\mathrm{ESI}$ & Emergy sustainability index: EYR/ELR \\
\hline
\end{tabular}

${ }^{a}$ Emergy indices were adapted from [33,34].

\section{Case Study}

A six-story educational building located in Chongqing, China, was adopted as a case study. The building was constructed in 1994 and had been in use for approximately 25 years. The building was chosen as the case study because it was deemed suitable to be renovated due to its obsolete and poor performance. The building has a gross floor area of $6500 \mathrm{~m}^{2}$, including a terrace on the third floor. The building story height is $3.6 \mathrm{~m}$, and the structure consists of bricks and reinforced concrete elements such as foundation footings, columns, beams, slabs and staircases. Its walls are constructed of red clay bricks, laid with cement mortar, which have been rendered and painted. The windows are single-glazing windows, and the roof is neither insulated nor waterproof. Inside the building, the floors are finished with ceramic tiles and terrazzo concrete. The interior walls and ceilings are plastered and painted.

\subsection{Reference Strategy}

Conservation strategies are often applied to historical buildings with a historical or cultural value. Therefore, a comparison was conducted of the refurbishment and rebuilding strategies.

The reference strategy is existing building before refurbishment or rebuilding. The list of required construction materials and technical specifications was obtained from project documents as developed by the architect and engineers. Based on the physical and functional parameters of the building, this paper assumed that the remaining life of the existing building is 10 years. Figure 3 shows an aerial view of the building.

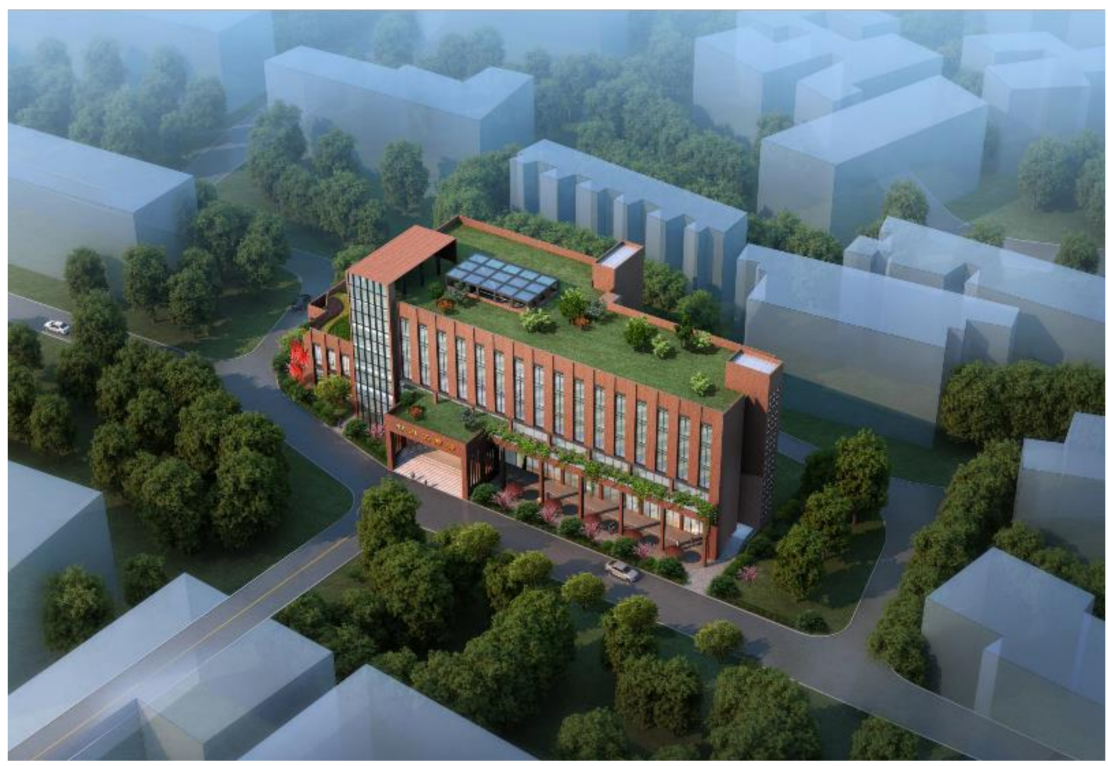

Figure 3. Aerial view of the building. 


\subsection{Refurbishment Strategy}

Refurbishment strategy included improving the building structure, functions and energy performance such as the addition of insulation to the walls, floors, and roof, the installation of new windows, and the fitting of energy-efficient electric appliances and lighting systems. The original building structure and foundation were preserved, but minor structural repairs were considered to strengthen and extend the building life span. The insulation performance of the building envelope may deteriorate over time due to several factors, such as the type of insulation, workmanship and level of exposure to weather conditions [73]. In this project, additional insulation to the walls, floors, and roof was suggested. It was proposed that all existing windows should be replaced due to their poor performance in thermal transmittance. Electric appliances such as air conditioners and lighting systems with high energy efficiency levels and savings were recommended. The life span of the building after refurbishment was assumed to be 20 years [74]. Figure 4 shows the plan of the second floor before and after refurbishment.

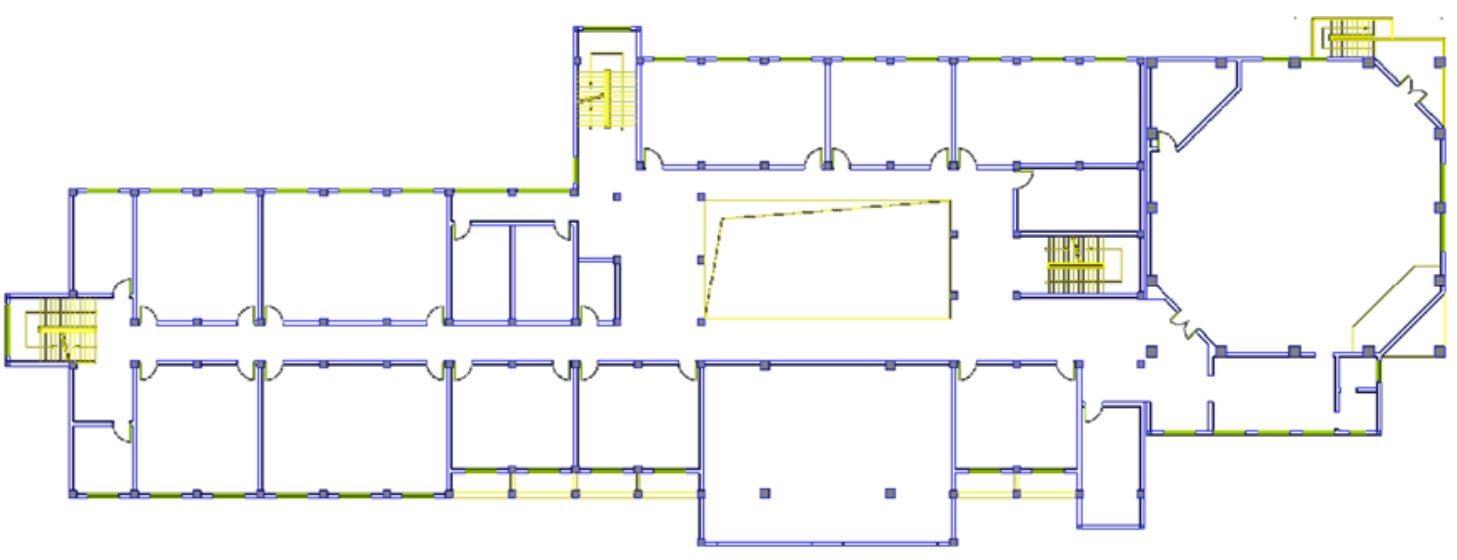

(a)

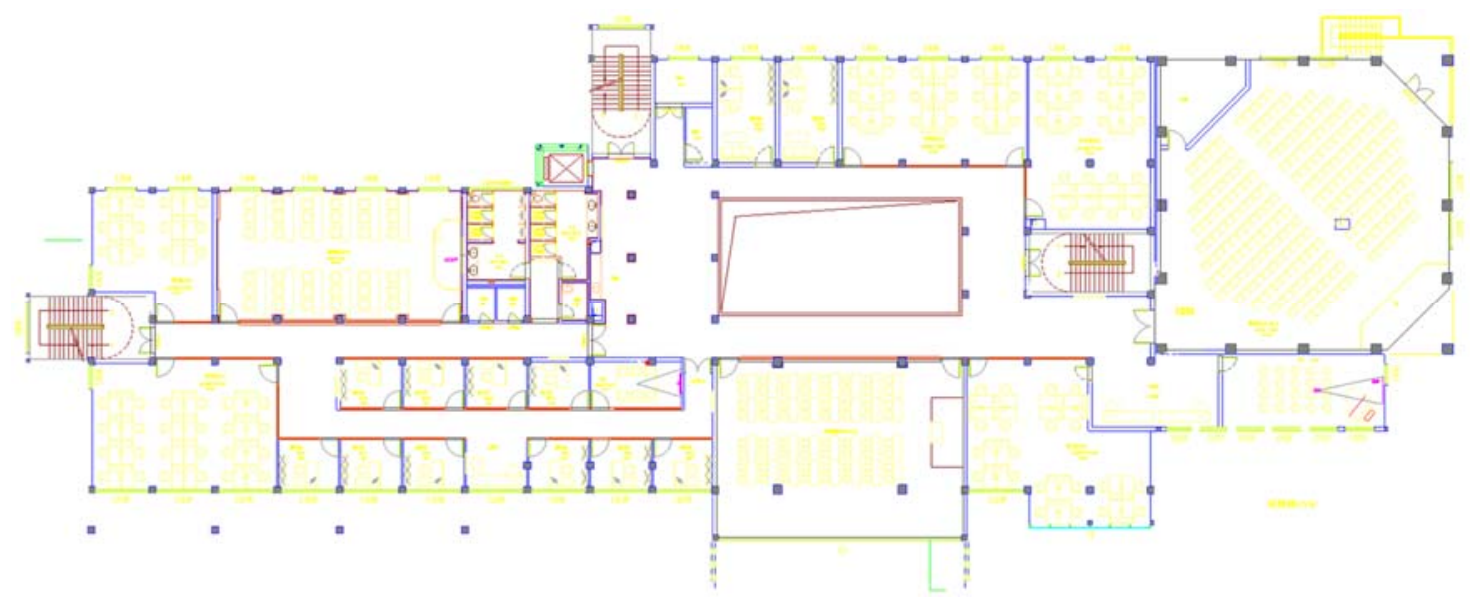

(b)

Figure 4. Second-floor plan. (a) Second-floor plan before refurbishment. (b) Second-floor plan after refurbishment.

\subsection{Rebuilding Strategy}

Rebuilding strategy in this case refers to the complete demolition of the existing building, thereby constructing a new building. According to national building regulations and standards, the new building must satisfy specific energy savings and seismic requirements. The new building would use reinforced concrete (RC) elements for its foundation, 
columns, beams and slabs. The interior layout, electric appliances and lighting systems were designed similar to those in the refurbishment strategy. The other substructures of the new building remained similar to those of the existing building for the sake of simplification. The lifespan of a new office building is often quoted to range from 40-75 years [75]. Therefore, the lifespan in this study was assumed as 60 years [26,28].

\subsection{Data Collection}

The renewal strategy data were obtained from relevant construction documents and project information. The collection of building data for the rebuilding strategy is time consuming and difficult due to the lack of construction documents. Therefore, this study obtained data from the documents pertaining to the existing building and the refurbishment strategy. In other words, this paper combines the documents of the existing building and information of the refurbishment strategy to obtain the construction documents for a new building in order to better calculate the co-benefits.

Once the list of building material quantities was compiled with the material flows in each strategy, the emergy of the input and output materials was calculated. The $\mathrm{CO}_{2}$ emissions in the different renewal measures was obtained by field measurements, simulation software from EnergyPlus 8.7 and the literature. Data on the solar transformity and certain emergy calculation processes were acquired from the literature. To conduct a better comparison, this study adopted 60 years as the research period, during which each strategy was implemented.

\section{Results}

The major emergy flows and co-benefits of the two renewal strategies are individually addressed and examined to compare their impacts and suggest the most suitable strategy.

\subsection{Emergy Flow}

\subsubsection{Resource Allocation}

An overview of the weight and emergy of resources required in the rebuilding strategy or the refurbishment strategy is presented on Tables 4 and 5. It is clear that comparing the lower emergy flow during demolition and end-of-life phase, $32.74 \%$ and $14.63 \%$ of the emergy flow was caused during the construction phase, $67.25 \%$ and $85.35 \%$ during the O\&M phase for the new building and the building after refurbishment, respectively. The emergy of the resources during the construction phase mainly consists of cement, concrete and gravel. The emergy of water and electricity during the O\&M phase is higher than other resources, which agrees with the function of the building as an educational building. The results suggest that the consumption of resource during the O\&M phase is the high and the importance of the resource management in O\&M phase [64].

Further, analysis of the weight of building materials in the construction phase reveals the quantities of materials such as concrete, cement, brick, lime, and sand used in the construction phase, which account for more than $80 \%$ of the total weight (Figure 5). The weight of concrete in the refurbishment strategy accounts for approximately $31.20 \%$ of the total weight, while that in the rebuilding strategy accounts for approximately $36.01 \%$, which implies that the concrete consumption level is the highest [76]. The relatively less consumed materials include wood, aluminum, and plastics. These results are consistent with the general understanding in the construction industry that the consumption of sand, concrete cement and bricks is high in the construction phase Gaspar and Santos [16]. 


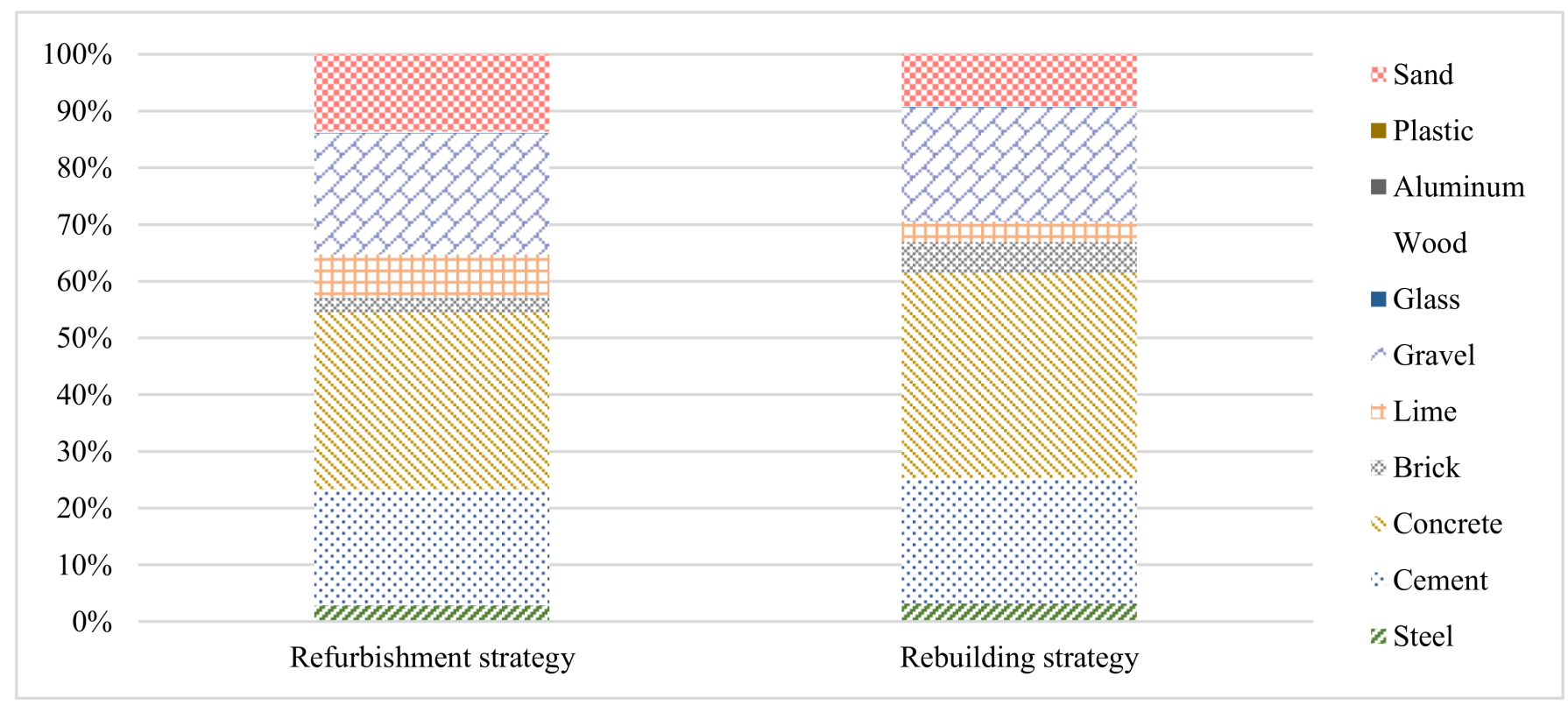

Figure 5. The weight of the building materials in the construction phase.

\subsubsection{GHG Emission}

To provide a complete picture of the environmental performance of the different renewal strategies, the $\mathrm{CO}_{2}$ emissions of the resources were calculated. Tables 6 and 7 contain detailed information on the $\mathrm{CO}_{2}$ emissions for the rebuilding and refurbishment strategies. It is clear that $11.5 \%$ of the $\mathrm{CO}_{2}$ emissions were generated in the building construction phase of the rebuilding strategy and $12.1 \%$ were generated in the refurbishment strategy. In the O\&M phase, the $\mathrm{CO}_{2}$ emissions were $88.5 \%$ in the rebuilding strategy and $87.9 \%$ in the refurbishment strategy. Notably, $\mathrm{O} \& \mathrm{M}$ phase is the largest contributor to $\mathrm{CO}_{2}$ emissions by comparing the life cycle $\mathrm{CO}_{2}$ emissions, followed by the construction phase $[62,63,77]$. The $\mathrm{CO}_{2}$ emissions of steel, concrete and cement together accounted for above $70 \%$ of the total emissions in both strategies. Relatively low emissions are associated with building materials such as wood, aluminum, glass, etc. In the O\&M phase, electricity is the most important factor impacting the environment due to the character of the consumed resources. The results indicate that in the construction phase, the type and quantity of building materials used has a far-reaching impact on the total carbon dioxide emissions [78]. 
Table 4. Emergy table for the rebuilding strategy.

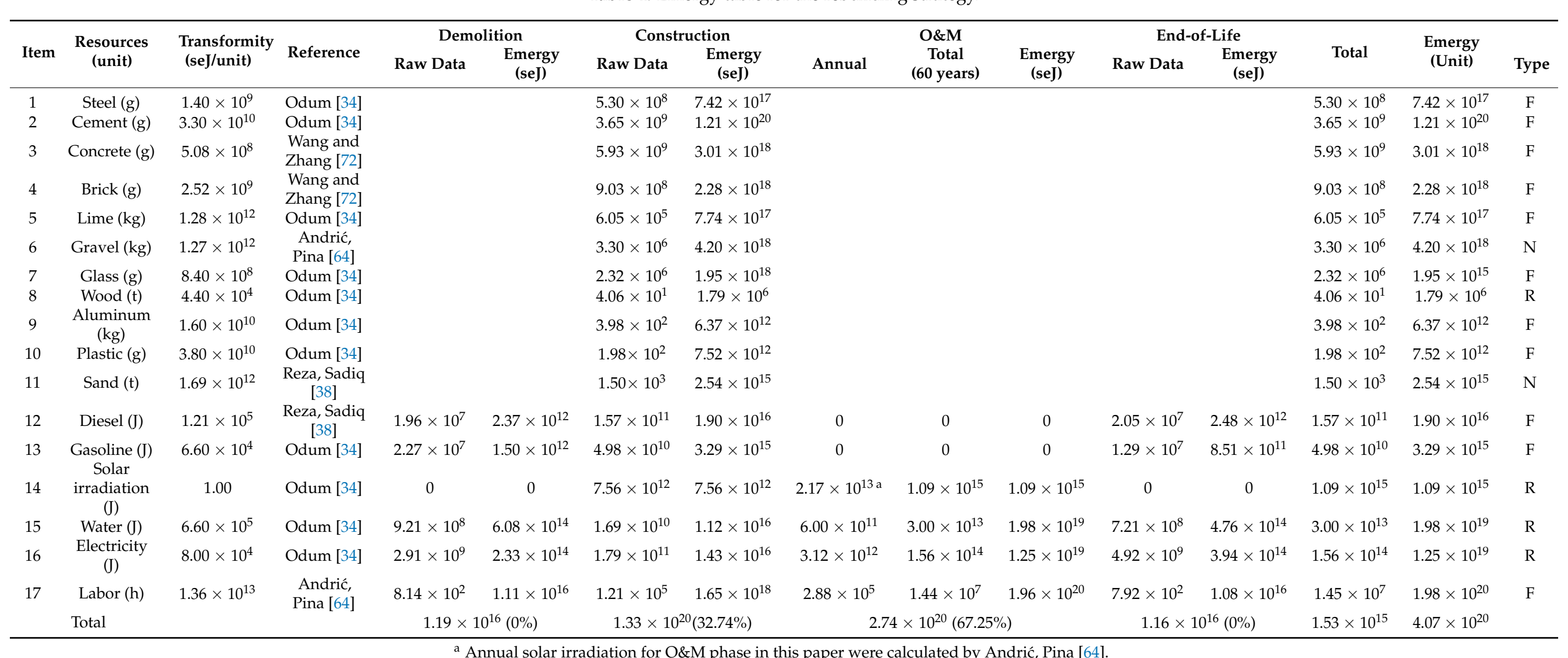

a Annual solar irradiation for O\&M phase in this paper were calculated by Andrić, Pina [64]. 
Table 5. Emergy table for the refurbishment strategy.

\begin{tabular}{|c|c|c|c|c|c|c|c|c|c|c|c|c|c|c|}
\hline \multirow[b]{2}{*}{ Item } & \multirow{2}{*}{$\begin{array}{l}\text { Resources } \\
\text { (unit) }\end{array}$} & \multirow{2}{*}{$\begin{array}{l}\text { Transformity } \\
\text { (seJ/unit) }\end{array}$} & \multicolumn{2}{|c|}{ Demolition } & \multicolumn{2}{|c|}{ Construction } & \multirow[b]{2}{*}{ Annual } & \multirow{2}{*}{$\begin{array}{c}\text { O\&M } \\
\text { Total } \\
\text { (20 Years) }\end{array}$} & \multirow[b]{2}{*}{$\begin{array}{l}\text { Emergy } \\
\text { (seJ) }\end{array}$} & \multicolumn{2}{|c|}{ End-of-Life } & \multirow[b]{2}{*}{ Total } & \multirow{2}{*}{$\begin{array}{c}\text { Emergy } \\
\text { (Unit) }\end{array}$} & \multirow{2}{*}{$\begin{array}{c}\text { Total } \\
\text { Emergy } \\
\text { (60 Years) }\end{array}$} \\
\hline & & & Raw Data & $\begin{array}{c}\text { Emergy } \\
\text { (seJ) }\end{array}$ & Raw Data & $\begin{array}{c}\text { Emergy } \\
\text { (seJ) }\end{array}$ & & & & Raw Data & $\begin{array}{c}\text { Emergy } \\
\text { (seJ) }\end{array}$ & & & \\
\hline 1 & Steel (g) & $1.40 \times 10^{9}$ & & & $2.04 \times 10^{8}$ & $2.86 \times 10^{17}$ & & & & & & $2.04 \times 10^{8}$ & $2.86 \times 10^{17}$ & $8.57 \times 10^{17}$ \\
\hline 2 & Cement (g) & $3.30 \times 10^{10}$ & & & $1.43 \times 10^{8}$ & $4.73 \times 10^{18}$ & & & & & & $1.43 \times 10^{8}$ & $4.73 \times 10^{18}$ & $1.42 \times 10^{19}$ \\
\hline 3 & Concrete (g) & $5.08 \times 10^{8}$ & & & $2.19 \times 10^{9}$ & $1.11 \times 10^{18}$ & & & & & & $2.19 \times 10^{9}$ & $1.11 \times 10^{18}$ & $3.34 \times 10^{18}$ \\
\hline 4 & Brick $(\mathrm{g})$ & $2.52 \times 10^{9}$ & & & $1.79 \times 10^{8}$ & $4.52 \times 10^{17}$ & & & & & & $1.79 \times 10^{8}$ & $4.52 \times 10^{17}$ & $1.36 \times 10^{18}$ \\
\hline 5 & Lime (kg) & $1.28 \times 10^{12}$ & & & $5.42 \times 10^{5}$ & $6.94 \times 10^{17}$ & & & & & & $5.42 \times 10^{5}$ & $6.94 \times 10^{17}$ & $2.08 \times 10^{18}$ \\
\hline 6 & Gravel (kg) & $1.27 \times 10^{12}$ & & & $1.49 \times 10^{6}$ & $1.90 \times 10^{18}$ & & & & & & $1.49 \times 10^{6}$ & $1.90 \times 10^{18}$ & $5.69 \times 10^{18}$ \\
\hline 7 & Glass (g) & $8.40 \times 10^{8}$ & & & $4.93 \times 10^{5}$ & $4.14 \times 10^{14}$ & & & & & & $4.93 \times 10^{5}$ & $4.14 \times 10^{14}$ & $1.24 \times 10^{15}$ \\
\hline 9 & $\underset{(\mathrm{kg})}{\text { Aluminum }}$ & $1.60 \times 10^{10}$ & & & $3.03 \times 10^{2}$ & $4.85 \times 10^{12}$ & & & & & & $3.03 \times 10^{2}$ & $4.85 \times 10^{12}$ & $1.45 \times 10^{13}$ \\
\hline 10 & Plastic (g) & $3.80 \times 10^{10}$ & & & $1.35 \times 10^{2}$ & $5.12 \times 10^{12}$ & & & & & & $1.35 \times 10^{2}$ & $5.12 \times 10^{12}$ & $1.54 \times 10^{13}$ \\
\hline 11 & Sand $(\mathrm{t})$ & $1.69 \times 10^{12}$ & & & $9.57 \times 10^{2}$ & $1.62 \times 10^{15}$ & & & & & & $9.57 \times 10^{2}$ & $1.62 \times 10^{15}$ & $4.85 \times 10^{15}$ \\
\hline 12 & Diesel (J) & $1.21 \times 10^{5}$ & $9.61 \times 10^{6}$ & $1.16 \times 10^{12}$ & $1.43 \times 10^{9}$ & $1.73 \times 10^{14}$ & 0 & 0 & 0 & $1.85 \times 10^{7}$ & $2.24 \times 10^{12}$ & $1.45 \times 10^{9}$ & $1.76 \times 10^{14}$ & $5.28 \times 10^{14}$ \\
\hline 13 & $\begin{array}{l}\text { Gasoline (J) } \\
\text { Solar }\end{array}$ & $6.60 \times 10^{4}$ & $1.06 \times 10^{7}$ & $7.02 \times 10^{11}$ & $3.82 \times 10^{8}$ & $2.52 \times 10^{13}$ & 0 & 0 & 0 & $6.59 \times 10^{7}$ & $4.35 \times 10^{12}$ & $4.59 \times 10^{8}$ & $3.03 \times 10^{13}$ & $9.09 \times 10^{13}$ \\
\hline 14 & $\begin{array}{l}\text { irradiation } \\
(\mathrm{J})\end{array}$ & 1.00 & 0 & 0 & $3.78 \times 10^{12}$ & $3.78 \times 10^{12}$ & $2.17 \times 10^{13 a}$ & $4.34 \times 10^{14}$ & $4.34 \times 10^{14}$ & 0 & 0 & $4.38 \times 10^{14}$ & $4.38 \times 10^{14}$ & $1.31 \times 10^{15}$ \\
\hline 15 & Water (J) & $6.60 \times 10^{5}$ & $6.49 \times 10^{8}$ & $4.28 \times 10^{14}$ & $5.84 \times 10^{8}$ & $3.85 \times 10^{14}$ & $6.00 \times 10^{11}$ & $1.20 \times 10^{13}$ & $7.92 \times 10^{18}$ & $6.86 \times 10^{8}$ & $4.53 \times 10^{14}$ & $1.20 \times 10^{13}$ & $7.92 \times 10^{18}$ & $2.38 \times 10^{19}$ \\
\hline 17 & $\begin{array}{l}\text { Labor (h) } \\
\text { Total }\end{array}$ & $1.36 \times 10^{13}$ & $\begin{array}{l}3.82 \times 10^{2} \\
5.72 \times 10\end{array}$ & $\begin{array}{l}5.20 \times 10^{15} \\
15(0.01 \%)\end{array}$ & $\begin{array}{r}4.97 \times 10^{5} \\
1.59 \times 10\end{array}$ & $\begin{array}{l}6.76 \times 10^{18} \\
(14.63 \%)\end{array}$ & $\begin{array}{r}2.88 \times 10^{5} \\
9.3\end{array}$ & $\begin{array}{c}5.76 \times 10^{6} \\
\times 10^{19}(85.35\end{array}$ & $7.83 \times 10^{19}$ & $\begin{array}{l}8.52 \times 10^{2} \\
1.24 \times 10\end{array}$ & $\begin{array}{l}1.16 \times 10^{16} \\
6(0.01 \%)\end{array}$ & $\begin{array}{c}6.26 \times 10^{6} \\
5.34 \times 10^{14}\end{array}$ & $\begin{array}{l}8.51 \times 10^{19} \\
1.09 \times 10^{20}\end{array}$ & $\begin{array}{l}2.55 \times 10^{20} \\
3.27 \times 10^{20}\end{array}$ \\
\hline
\end{tabular}

a Annual solar irradiation for O\&M phase in this paper were calculated by Andrić, Pina [64]. 
Table 6. $\mathrm{CO}_{2}$ emissions in the rebuilding strategy.

\begin{tabular}{|c|c|c|c|c|c|c|c|c|c|c|c|}
\hline Item & $\begin{array}{l}\text { Resources } \\
\text { (Unit) }\end{array}$ & $\begin{array}{c}\text { Emission } \\
\text { Factor (kg/unit) }\end{array}$ & Demolition & Emission & Construction & Emission & Annual & $\begin{array}{c}\text { Annual } \\
\text { Emission }\end{array}$ & $\begin{array}{c}\text { O\&M } \\
\text { Emission }\end{array}$ & End-of-Life & Emission \\
\hline 1 & Steel (kg) & 2.208 & & & $5.30 \times 10^{5}$ & $1.17 \times 10^{6}$ & & & & & \\
\hline 2 & Cement (kg) & 0.894 & & & $3.65 \times 10^{6}$ & $3.27 \times 10^{6}$ & & & & & \\
\hline 3 & Concrete $(\mathrm{kg})$ & 0.242 & & & $5.93 \times 10^{6}$ & $1.44 \times 10^{6}$ & & & & & \\
\hline 4 & Brick $(\mathrm{kg})$ & 0.2 & & & $9.03 \times 10^{5}$ & $1.81 \times 10^{5}$ & & & & & \\
\hline 5 & Lime (kg) & 1.2 & & & $6.05 \times 10^{4}$ & $7.25 \times 10^{4}$ & & & & & \\
\hline 6 & Gravel (kg) & 0.002 & & & $3.30 \times 10^{6}$ & $6.61 \times 10^{3}$ & & & & & \\
\hline 7 & Glass (kg) & 1.4 & & & $2.32 \times 10^{3}$ & $3.25 \times 10^{3}$ & & & & & \\
\hline 9 & Aluminum (kg) & 1.407 & & & $3.98 \times 10^{2}$ & $5.60 \times 10^{2}$ & & & & & \\
\hline 10 & Sand $(\mathrm{kg})$ & 0.0069 & & & $1.50 \times 10^{6}$ & $1.04 \times 10^{4}$ & & & & & \\
\hline 11 & Diesel (L) & 2.73 & $6.98 \times 10^{-1}$ & 1.91 & $5.59 \times 10^{3}$ & $1.53 \times 10^{4}$ & 0 & 0 & 0 & $7.31 \times 10^{-1}$ & 1.99 \\
\hline 12 & Gasoline (L) & 2.26 & $6.17 \times 10^{-1}$ & 1.39 & $1.35 \times 10^{3}$ & $3.06 \times 10^{3}$ & 0 & 0 & 0 & $3.51 \times 10^{-1}$ & $7.92 \times 10^{-1}$ \\
\hline \multirow[t]{2}{*}{13} & Electricity (kWh) & 0.9229 & $8.08 \times 10^{2}$ & $7.46 \times 10^{2}$ & $4.97 \times 10^{4}$ & $4.59 \times 10^{4}$ & $8.66 \times 10^{5}$ & $7.99 \times 10^{5}$ & $4.79 \times 10^{7}$ & $1.37 \times 10^{3}$ & $1.26 \times 10^{3}$ \\
\hline & Total & & & $7.49 \times 10^{2}$ & & $6.22 \times 10^{6}$ & & & $4.79 \times 10^{7}$ & & $1.26 \times 10^{3}$ \\
\hline
\end{tabular}

Table 7. $\mathrm{CO}_{2}$ emissions in the refurbishment strategy.

\begin{tabular}{|c|c|c|c|c|c|c|c|c|c|c|c|}
\hline Item & $\begin{array}{l}\text { Resources } \\
\text { (Unit) }\end{array}$ & $\begin{array}{c}\text { Emission Factor } \\
\text { (kg/unit) }\end{array}$ & Demolition & Emission & Construction & Emission & Annual & $\begin{array}{c}\text { Annual } \\
\text { Emission }\end{array}$ & $\begin{array}{c}\text { O\&M } \\
\text { Emission }\end{array}$ & End-of-Life & Emission \\
\hline 1 & Steel (kg) & 2.208 & & & $2.04 \times 10^{5}$ & $4.50 \times 10^{5}$ & & & & & \\
\hline 2 & Cement $(\mathrm{kg})$ & 0.894 & & & $1.43 \times 10^{6}$ & $1.28 \times 10^{6}$ & & & & & \\
\hline 3 & Concrete (kg) & 0.242 & & & $2.19 \times 10^{6}$ & $5.31 \times 10^{5}$ & & & & & \\
\hline 4 & Brick (kg) & 0.2 & & & $1.79 \times 10^{5}$ & $3.59 \times 10^{4}$ & & & & & \\
\hline 5 & Lime (kg) & 1.2 & & & $5.42 \times 10^{5}$ & $6.51 \times 10^{5}$ & & & & & \\
\hline 6 & Gravel (kg) & 0.002 & & & $1.49 \times 10^{6}$ & $2.99 \times 10^{3}$ & & & & & \\
\hline 7 & Glass (kg) & 1.4 & & & $4.93 \times 10^{2}$ & $6.90 \times 10^{2}$ & & & & & \\
\hline 8 & Wood (kg) & 0.2 & & & $2.52 \times 10^{4}$ & $5.04 \times 10^{3}$ & & & & & \\
\hline 9 & Aluminum (kg) & 1.407 & & & $3.03 \times 10^{2}$ & $4.26 \times 10^{2}$ & & & & & \\
\hline 10 & Sand $(\mathrm{kg})$ & 0.0069 & & & $9.57 \times 10^{5}$ & $6.61 \times 10^{3}$ & & & & & \\
\hline 11 & Diesel (L) & 2.73 & $3.42 \times 10^{-1}$ & $9.35 \times 10^{-1}$ & $5.08 \times 10^{1}$ & $1.39 \times 10^{2}$ & 0 & 0 & 0 & $6.59 \times 10^{-1}$ & 1.80 \\
\hline 12 & Gasoline (L) & 2.26 & $2.89 \times 10^{-1}$ & $6.53 \times 10^{-1}$ & $1.04 \times 10^{1}$ & $2.45 \times 10^{1}$ & 0 & 0 & 0 & 1.79 & 4.05 \\
\hline \multirow[t]{2}{*}{13} & Electricity (kWh) & 0.9229 & $3.25 \times 10^{2}$ & $3.00 \times 10^{2}$ & $4.94 \times 10^{2}$ & $4.56 \times 10^{2}$ & $1.17 \times 10^{6}$ & $1.08 \times 10^{6}$ & $2.16 \times 10^{7}$ & $1.12 \times 10^{3}$ & $1.03 \times 10^{3}$ \\
\hline & Total & & & $3.02 \times 10^{2}$ & & $2.97 \times 10^{6}$ & & & $2.16 \times 10^{7}$ & & $1.04 \times 10^{3}$ \\
\hline
\end{tabular}




\subsection{Co-Benefits}

\subsubsection{Resource Allocation}

The emergy of the resources invested in the building system is illustrated in Figure 6. It is clear that the emergy is highest during the construction phase of the rebuilding strategy, followed by the refurbishment strategy, and finally the existing building, which indicated that the large number of materials were required in the construction phase. The annual emergy in O\&M phase of rebuilding strategy, reference strategy and refurbishment strategy were $4.56 \times 10^{18}$ seJ, $6.39 \times 10^{18}$ seJ, $4.65 \times 10^{18}$ seJ, respectively, which concluded that resource consumption of rebuilding strategy and refurbishment strategy in O\&M phase is lower than existing building and the co-benefits of renewal strategies over existing building. Emergy of the new building during O\&M phase is lower than refurbished building. However, the total emergy in the rebuilding strategy $\left(4.07 \times 10^{20} \mathrm{seJ}\right)$ is the largest one among the three strategies as newer materials are used for the building, in line with a more complex practice and higher energy saving standard [16]. The minimum emergy value was attained for the refurbishment strategy, which shown the co-benefits of refurbishment strategy is higher than the rebuilding strategy.

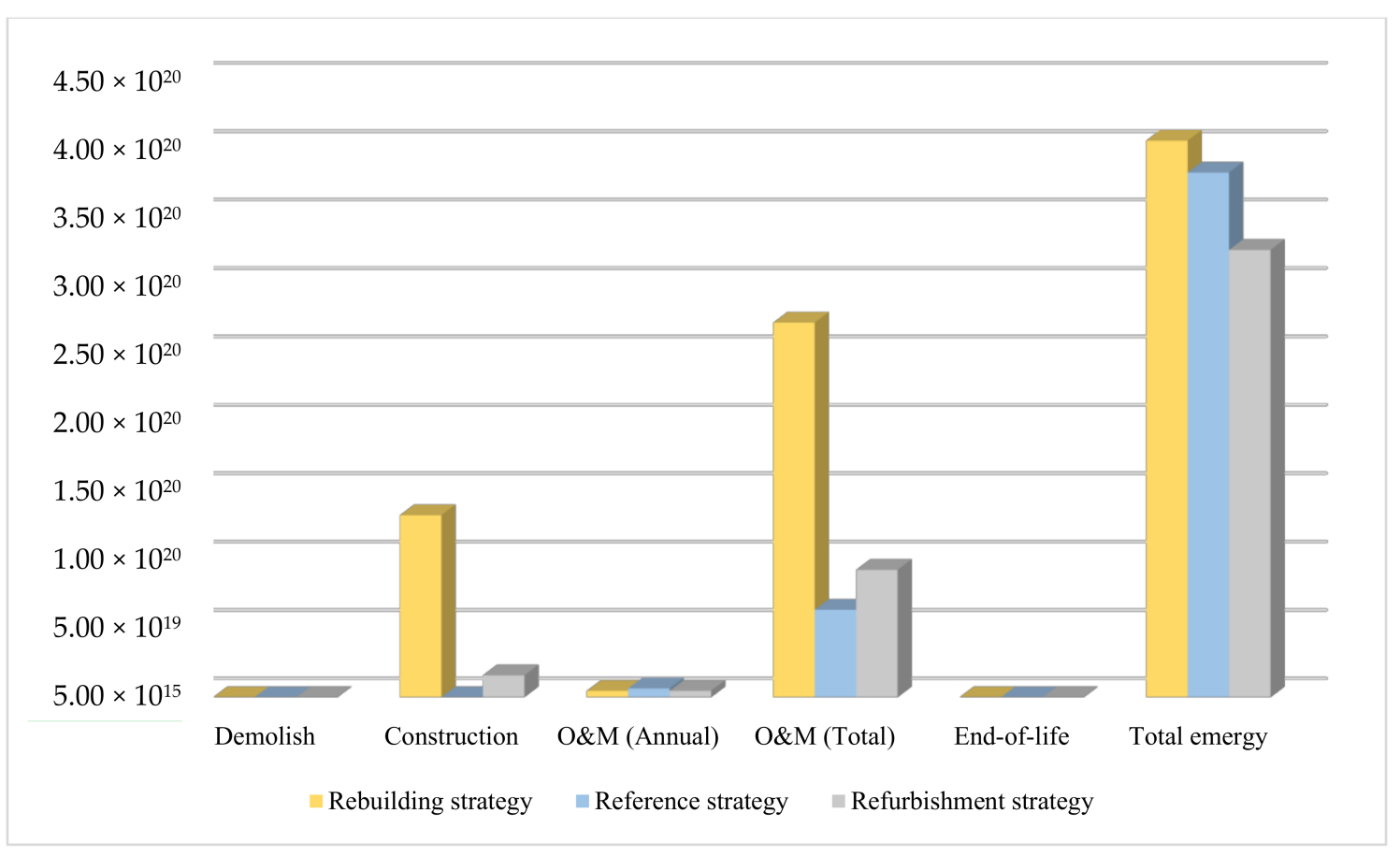

Figure 6. Emergy values in the life cycle phases of the different strategies.

\subsubsection{GHG Emissions}

Figure 7 shows the $\mathrm{CO}_{2}$ emissions in each phase of the life cycle and the total emissions. It is clear that rebuilding strategy contribute more $\mathrm{CO}_{2}$ emissions than refurbishment strategy during construction phase as large amount of building materials were used. During the $\mathrm{O} \& \mathrm{M}$ phase, the annual $\mathrm{CO}_{2}$ emissions of rebuilding, refurbishment and reference strategy were estimated as $7.99 \times 10^{5} \mathrm{~kg}, 1.08 \times 10^{6} \mathrm{~kg}$ and $1.53 \times 10^{6} \mathrm{~kg}$, respectively. Meanwhile the total $\mathrm{CO}_{2}$ emissions of rebuilding strategy during O\&M phase is the most, followed by refurbishment strategy due to the different O\&M time. It is clear that the rebuilding and refurbishment strategies released approximately $59.1 \%$ and $80.6 \%$, respectively, of the total $\mathrm{CO}_{2}$ emissions that would be produced by the existing building. Thus, the total $\mathrm{CO}_{2}$ emissions over the entire building life cycle is lower than existing building for both renewal strategies. The comparison of life cycle $\mathrm{CO}_{2}$ emissions demonstrated that substantial environmental benefits can be obtained in both the refurbishment and rebuilding strategies $[60,77]$. On the other hand, the total $\mathrm{CO}_{2}$ emissions of rebuilding 
strategy is lower than refurbishment strategy during the research period, which is clearly in favor of the rebuilding strategy $[25,26]$.

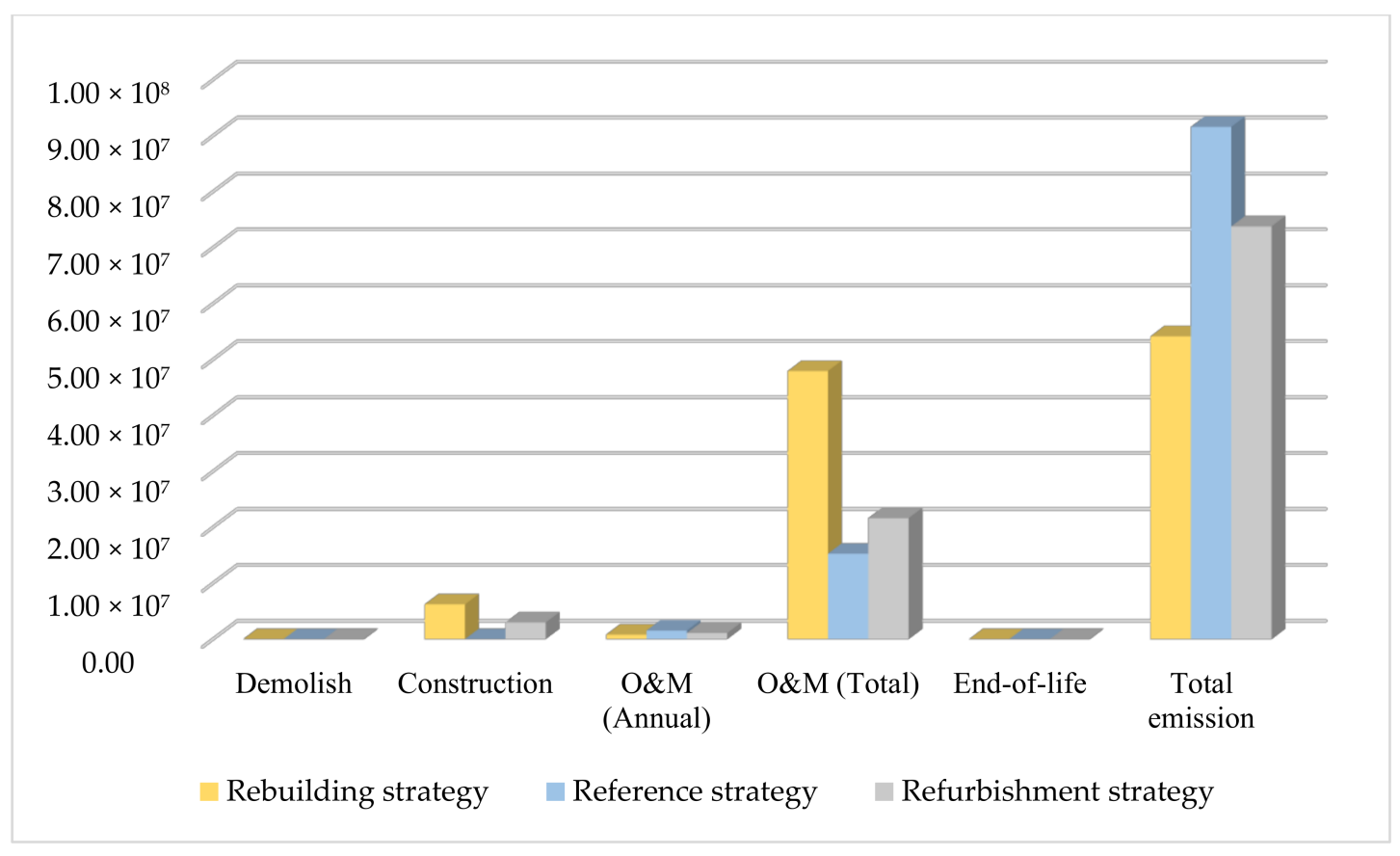

Figure 7. The $\mathrm{CO}_{2}$ emissions in the life cycle phases of the different strategies.

\subsubsection{The Emergy-Based Indicators}

Table 8 summarizes the total emergy invested in the building system and the $\mathrm{CO}_{2}$ emissions released by the system after implementing the different renewal strategies during the research period (60 years). The results indicate that the best strategy to realize the highest co-benefits is the reference strategy as consumed the least resources. On the other hand, the best strategy is the rebuilding strategy in terms of the total GHG emissions. Therefore, certain emergy-based indicators were calculated to explain the co-benefits.

Table 8. Total emergy and total $\mathrm{CO}_{2}$ emissions in the three strategies.

\begin{tabular}{ccc}
\hline Emergy & Emergy (seJ) & CO $_{2}$ Emission (kg) \\
\hline Rebuilding strategy & $4.07 \times 10^{20}$ & $5.41 \times 10^{7}$ \\
Reference strategy & $2.87 \times 10^{20}$ & $9.16 \times 10^{7}$ \\
Refurbishment strategy & $3.27 \times 10^{20}$ & $7.38 \times 10^{7}$ \\
\hline
\end{tabular}

Table 9 provides a detailed information of the emergy-based indicators about three strategies. By comparing the different strategies, it can be concluded that the EYR for the rebuilding strategy, reference strategy and refurbishment strategy is 1.12, 1.08 and 1.18, respectively, which indicate that the implementation of building refurbishment measures performs better considering that less resources are required to generate greater benefits. The ELR (Environmental loading ratio) and ESI (Emergy sustainability index) reflect the environmental performance of the building system. It is clear that the ELR for the rebuilding strategy is 9.51, which is higher than that for the refurbishment strategy, and the ESI for the rebuilding strategy is lower than that for the refurbishment strategy, which indicates that the refurbishment strategy performs better from the perspective of the environment. Therefore, the refurbishment strategy is more suitable than the rebuilding strategy. 
Table 9. Emergy-based indicators.

\begin{tabular}{cccc}
\hline Emergy Indices & Rebuilding Strategy & Reference Strategy & Refurbishment Strategy \\
\hline R & $3.87 \times 10^{19}$ & $5.93 \times 10^{18}$ & $1.47 \times 10^{19}$ \\
N & $4.20 \times 10^{18}$ & 0.00 & $1.90 \times 10^{18}$ \\
F & $3.64 \times 10^{20}$ & $7.24 \times 10^{19}$ & $9.24 \times 10^{19}$ \\
Y & $4.07 \times 10^{20}$ & $7.83 \times 10^{19}$ & $1.09 \times 10^{20}$ \\
EYR & 1.12 & 1.08 & 1.18 \\
ELR & 9.51 & 12.21 & 6.43 \\
ESI & 0.12 & 0.09 & 0.18 \\
\hline
\end{tabular}

\section{Discussion}

The proposed method was used to investigate the emergy flow and co-benefits of different urban renewal strategies. The values for the resource allocation, GHG emissions and the emergy-based indicators of three renewal strategies were presented. The emergy of renewal strategies showed that the refurbishment or rebuilding of existing building resulted in a reduction in the annual emergy and GHG emissions of the building. The reason was perhaps that the energy performance of envelope and HVAC system was improved after enhancing thermal performance of the external walls, roof, door and other envelope elements and replace the low energy efficient windows and HVAC system with a high one $[64,79,80]$. The results were also consistent with the study of Andric and Jradi, indicating that the renewal strategies were indeed better than that of existing building $[64,81]$.

For refurbishment strategy and rebuilding strategy, it is clearly shown that the rebuilding strategy has the higher total emergy value, while the value of per year is lower than refurbishment strategy. The reason for it may be the use of large amount of building materials and machines in construction phase and the more complex practice and higher energy saving standard [16]. From the perspective of GHG emissions, the total GHG emissions of rebuilding strategy $\left(5.41 \times 10^{7} \mathrm{~kg}\right)$ is lower than refurbishment strategy $\left(7.38 \times 10^{7}\right)$ during the research period, which means rebuilding strategy have a better performance than refurbishment. The results were also consistent with the research of Feng et al. and Rønning et al., which in favor of the rebuilding strategy [25,26]. However, the emegy-based indicators of rebuilding strategy perform worse than refurbishment strategy. The reason was perhaps that the total emergy of rebuilding strategy is higher than that of refurbishment, which resulted in the reduction of whole performance.

\section{Conclusions}

Urban renewal is a promising solution for coping with city aging and urban environment through different strategies, such as redevelopment, refurbishment and conservation. However, selecting the appropriate strategy for sustainable urban renewal remains unclear based on the existing literature. Under such circumstances, the EM-LCA approach combining Em and LCA was adopted in this study to compare the co-benefits of rebuilding strategy with refurbishment strategy based on a case study. Emergy flows and GHG emissions in different strategies and their co-benefits over existing building were analyzed during the life cycle of the building in the case study.

The results in this case demonstrate that a large quantity of materials was consumed in the construction phase, among which concrete, cement and brick accounted for a large portion. The annual emergy in O\&M phase of rebuilding strategy and refurbishment strategy is lower than the existing building. However, the total emergy of rebuilding strategy is higher than the existing building because of the large amount of materials consumption in construction phase, which suggest that the refurbishment strategy is a better choice. In terms of GHG emissions, the highest $\mathrm{CO}_{2}$ emissions occurred in the O\&M phase, which accounted for more than $85 \%$ of the $\mathrm{CO}_{2}$ emissions during the whole life cycle. The rebuilding strategy and refurbishment strategy released lower GHG emissions, which account for $59.1 \%$ and $80.6 \%$ of the total GHG emissions that produced by the 
existing building. On the other hand, it can be concluded that the EYR for the rebuilding strategy is higher than refurbishment strategy, which demonstrate the better performance of refurbishment considering that less resources are required to generate greater benefits. Additionally, the value of ELR and ESI also suggests that the refurbishment strategy performs better from the perspective of the environment. Thereby, the refurbishment strategy is more suitable than the rebuilding strategy.

This paper presents an effective and comprehensive method to assess the impact of different renewal strategies, which is highly relevant and useful for many future renewal projects. Furthermore, the findings of this study may be helpful to decision-makers when choosing the appropriate strategy and have a far-reaching effect on policy implementation. Additionally, this study may be useful to academics, as it possibly represents another study area, such as the comparison of the aforementioned three strategies in community level. However, the study had some important limitations as the emergy flow and GHG emissions of renewal strategies are calculated using current data. Moreover, it did not consider the social impacts, which is also significant for implementing urban renewal projects.

Author Contributions: W.C., J.H., and G.L. conceived and planned the review. W.C., Y.H. and L.Z. performed the search and analyzed the data. W.C. and J.H. wrote the paper. G.L. and K.L. revised the article critically. All authors have read and agreed to the published version of the manuscript.

Funding: This research was funded by [the National Natural Science Foundation of China] grant number [71802030], [the Humanities and Social Science Fund of Ministry of Education of China] grant number [18YJC630071], [the Fundamental Research Funds for the Central Universities] grant number [2019CDJSK03XK14].

Institutional Review Board Statement: Not applicable.

Informed Consent Statement: Not applicable.

Data Availability Statement: The data presented in this study are available on request from the corresponding author.

Conflicts of Interest: The authors declare no conflict of interest.

\section{Nomenclature}

\begin{tabular}{|c|c|c|c|}
\hline \multicolumn{4}{|l|}{ Acronyms } \\
\hline BIM & Building information modelling & $i$ & material $i$ \\
\hline $\mathrm{CO}_{2}$ & Carbon dioxide & LCA & Life cycle assessment \\
\hline Em & Emergy & LCC & Life cycle cost \\
\hline EM-LCA & $\begin{array}{l}\text { Combination of emergy and } \\
\text { LCA method }\end{array}$ & $\mathrm{N}$ & Nonrenewable resources \\
\hline ELR & Environmental loading ratio & O\&M & $\begin{array}{l}\text { Operation and maintenance } \\
\text { phase }\end{array}$ \\
\hline ESI & Emergy sustainability index & $\mathrm{R}$ & Renewable resources \\
\hline EYR & Emergy yield ratio & $\mathrm{RC}$ & Reinforced concrete \\
\hline $\mathrm{F}$ & Emergy feedback & $\mathrm{Y}$ & Emergy yield \\
\hline GHG & Greenhouse gas & & \\
\hline \multicolumn{4}{|c|}{ Variables and parameters } \\
\hline$c_{d}$ & Calorific value of diesel fuel (J) & $N_{h}$ & $\begin{array}{l}\text { Number of working hours } \\
\text { per day of one employee (h) }\end{array}$ \\
\hline$c_{g}$ & Calorific value of gasoline $(\mathrm{J})$ & $N_{n}$ & Number of employees \\
\hline$E_{\mathrm{CO}_{2}-e q}$ & $\begin{array}{l}\text { Emission factor of the different } \\
\text { building materials } i \text { (kg/unit) }\end{array}$ & $S$ & $\begin{array}{l}\text { construction site surface } \\
\text { (footprint) }\left(\mathrm{m}^{2}\right)\end{array}$ \\
\hline$E_{d}$ & $\begin{array}{l}\text { Solar emergy of the diesel fuel } \\
\text { consumed (seJ) }\end{array}$ & $t_{c}$ & Construction time (year) \\
\hline
\end{tabular}




\begin{tabular}{|c|c|c|c|}
\hline$E_{e}$ & $\begin{array}{l}\text { Solar emergy of the electricity } \\
\text { required in the building } \\
\text { construction, O\&M and } \\
\text { end-of-life phases (seJ) }\end{array}$ & $\mathrm{T}_{d}$ & $\begin{array}{l}\text { Transformity of diesel fuel } \\
\text { (seJ/unit) }\end{array}$ \\
\hline$E_{g}$ & Solar emergy of gasoline (seJ) & $T_{e}$ & $\begin{array}{l}\text { Transformity of electricity } \\
\text { (seJ/unit) }\end{array}$ \\
\hline$E_{l}$ & $\begin{array}{l}\text { Solar emergy equivalent of } \\
\text { human labor (seJ) }\end{array}$ & $\mathrm{T}_{g}$ & $\begin{array}{l}\text { Transformity of gasoline } \\
\text { (seJ/unit) }\end{array}$ \\
\hline$E_{m}$ & $\begin{array}{l}\text { Solar emergy of the building } \\
\text { materials (seJ) }\end{array}$ & $\mathrm{T}_{l}$ & $\begin{array}{l}\text { Transformity of labor } \\
\text { (seJ/unit) }\end{array}$ \\
\hline$E_{s, c}$ & $\begin{array}{l}\text { Solar emergy of the solar } \\
\text { irradiation in the construction } \\
\text { phase (seJ) }\end{array}$ & $T_{m i}$ & $\begin{array}{l}\text { Transformity of material } i \\
\text { (seJ/unit) }\end{array}$ \\
\hline$E_{w, c}$ & $\begin{array}{l}\text { Solar emergy of the water } \\
\text { consumed in the building } \\
\text { demolition, construction and } \\
\text { end-of-life phases (seJ) }\end{array}$ & $T_{S}$ & $\begin{array}{l}\text { Transformity of solar energy } \\
\text { (seJ/unit) }\end{array}$ \\
\hline$E_{w, o}$ & $\begin{array}{l}\text { Solar emergy of the water } \\
\text { consumed in the building O\&M } \\
\text { phase (seJ) }\end{array}$ & $T_{w}$ & $\begin{array}{l}\text { Transformity of water } \\
\text { (seJ/unit) }\end{array}$ \\
\hline G & Gibbs free energy of water $(\mathrm{J} / \mathrm{g})$ & $t_{o}$ & $\begin{array}{l}\text { Total number of working } \\
\text { days per year (day) }\end{array}$ \\
\hline$I$ & $\begin{array}{l}\text { Annual amount of solar } \\
\text { radiation }\left(\mathrm{J} / \mathrm{m}^{2}\right)\end{array}$ & $t_{t}$ & $\begin{array}{l}\text { Working days required in the } \\
\text { life cycle process (day) }\end{array}$ \\
\hline $\mathrm{G}_{\mathrm{CO}_{2}}$ & Amount of $\mathrm{CO}_{2}$ emissions $(\mathrm{kg})$ & $V_{a}$ & $\begin{array}{l}\text { Required water volume of } \\
\text { one person per day }\left(\mathrm{m}^{3}\right)\end{array}$ \\
\hline$M_{d}$ & $\begin{array}{l}\text { Quantity of diesel fuel } \\
\text { consumed in the building life } \\
\text { cycle (L) }\end{array}$ & $V$ & Required water volume $\left(\mathrm{m}^{3}\right)$ \\
\hline$M_{g}$ & $\begin{array}{l}\text { Quantity of gasoline consumed } \\
\text { in the building life cycle (L) }\end{array}$ & $W$ & Quantity of electricity (kWh) \\
\hline$M_{i}$ & Quantity of material $i$ & $\rho$ & Water density $\left(\mathrm{kg} / \mathrm{m}^{3}\right)$ \\
\hline
\end{tabular}

\section{References}

1. Ohnishi, S.; Dong, H.; Geng, Y.; Fujii, M.; Fujita, T. A comprehensive evaluation on industrial \& urban symbiosis by combining MFA, carbon footprint and emergy methods-Case of Kawasaki, Japan. Ecol. Indic. 2017, 73, 513-524. [CrossRef]

2. Liu, G.; Wei, L.; Gu, J.; Zhou, T.; Liu, Y. Benefit distribution in urban renewal from the perspectives of efficiency and fairness: A game theoretical model and the government's role in China. Cities 2020, 96, 1-9. [CrossRef]

3. Liu, Y.; Zhu, A.-X.; Wang, J.; Li, W.; Hu, G.; Hu, Y. Land-use decision support in brownfield redevelopment for urban renewal based on crowdsourced data and a presence-and-background learning (PBL) method. Land Use Policy 2019, 88, 104188. [CrossRef]

4. Zheng, W.; Shen, G.Q.; Wang, H.; Hong, J.; Li, C.Z. Decision support for sustainable urban renewal: A multi-scale model. Land Use Policy 2017, 69, 361-371. [CrossRef]

5. Huang, L.; Zheng, W.; Hong, J.; Liu, Y.; Liu, G. Paths and strategies for sustainable urban renewal at the neighbourhood level: A framework for decision-making. Sustain. Cities Soc. 2020, 55, 102074. [CrossRef]

6. Sharghi, A.; Jahanzamin, Y.; Ghanbaran, A.; Jahanzamin, S. A study on evolution and development of urban regenera-tion with emphasis on the cultural approach. Turk. Online J. Des. Art Commun. 2018, 8, 271-284. [CrossRef]

7. Zheng, H.W.; Shen, G.Q.; Wang, H. A review of recent studies on sustainable urban renewal. Habitat Int. 2014, 41, 272-279. [CrossRef]

8. Xu, Y.; Liu, M.; Hu, Y.; Li, C.; Xiong, Z. Analysis of Three-Dimensional Space Expansion Characteristics in Old Industrial Area Re-newal Using GIS and Barista: A Case Study of Tiexi District, Shenyang, China. Sustainability 2019, 11, 1860. [CrossRef]

9. Ho, D.C.W.; Yau, Y.; Poon, S.W.; Liusman, E. Achieving Sustainable Urban Renewal in Hong Kong: Strategy for Dilapidation Assessment of High Rises. J. Urban Plan. Dev. 2012, 138, 153-165. [CrossRef]

10. Yau, Y.; Chan, H.L. To rehabilitate or redevelop? A study of the decision criteria for urban regeneration projects. J. Place Manag. Dev. 2008, 1, 272-291. [CrossRef]

11. Fung, W.B.; Yau, Y. Weightings of decision-making criteria for neighbourhood renewal: Perspectives of university students in Hong Kong. J. Urban Regen. Renew. 2009, 2, 238-258. 
12. Dubois, M.; Allacker, K. Energy savings from housing: Ineffective renovation subsidies vs efficient demolition and reconstruction incentives. Energy Policy 2015, 86, 697-704. [CrossRef]

13. Yung, E.H.K.; Zhang, Q.; Chan, E.H.W. Underlying social factors for evaluating heritage conservation in urban renewal districts. Habitat Int. 2017, 66, 135-148. [CrossRef]

14. Meex, E.; Hollberg, A.; Knapen, E.; Hildebrand, L.; Verbeeck, G. Requirements for applying LCA-based environmental impact assessment tools in the early stages of building design. Build. Environ. 2018, 133, 228-236. [CrossRef]

15. Ferrante, A.; Semprini, G. Building energy retrofitting in urban areas. Procedia Eng. 2011, 21, 968-975. [CrossRef]

16. Gaspar, P.L.; Santos, A.L. Embodied energy on refurbishment vs. demolition: A southern Europe case study. Energy Build. 2015, 87, 386-394. [CrossRef]

17. Franzoni, E.; Volpi, L.; Bonoli, A.; Spinelli, R.; Gabrielli, R. The environmental impact of cleaning materials and technologies in heritage buildings conservation. Energy Build. 2018, 165, 92-105. [CrossRef]

18. Ascione, F.; Cheche, N.; De Masi, R.F.; Minichiello, F.; Vanoli, G.P. Design the refurbishment of historic buildings with the cost-optimal methodology: The case study of a XV century Italian building. Energy Build. 2015, 99, 162-176. [CrossRef]

19. Fabbri, K. Energy incidence of historic building: Leaving no stone unturned. J. Cult. Herit. 2013, 14, e25-e27. [CrossRef]

20. Power, A. Does demolition or refurbishment of old and inefficient homes help to increase our environmental, social and economic viability? Energy Policy 2008, 36, 4487-4501. [CrossRef]

21. Marique, A.-F; Rossi, B. Cradle-to-grave life-cycle assessment within the built environment: Comparison between the refurbishment and the complete reconstruction of an office building in Belgium. J. Environ. Manag. 2018, 224, 396-405. [CrossRef] [PubMed]

22. Weiler, V.; Harter, H.; Eicker, U. Life cycle assessment of buildings and city quarters comparing demolition and reconstruction with refurbishment. Energy Build. 2017, 134, 319-328. [CrossRef]

23. Vaclav, H.; Elizabeth, E.; Roderick, B.; Stephanie, C.; Billie, F.; Bilec, M.M. Comparative whole-building life cycle assessment of renovation and new construction. Build. Environ. 2019, 161, 106218.

24. Thomsen, A.; Flier, K.V.d. Replacement or renovation of dwellings: The relevance of a more sustainable approach. Build. Res. Inf. 2009. [CrossRef]

25. Feng, H.; Liyanage, D.R.; Karunathilake, H.; Sadiq, R.; Hewage, K. BIM-based life cycle environmental performance assessment of single-family houses: Renovation and reconstruction strategies for aging building stock in British Columbia. J. Clean. Prod. 2020, 250, 119543. [CrossRef]

26. Rønning, A.; Vold, M.; Nereng, G. Refurbishment or Replacement of Buildings-What is Best for the Climate? In Proceedings of the Conference Join Action on Climate Change Economics, Aalborg, Denmark, 8-10 June 2009.

27. Ferreira, J.; Pinheiro, M.D.; De Brito, J. Economic and environmental savings of structural buildings refurbishment with demolition and reconstruction-A Portuguese benchmarking. J. Build. Eng. 2015, 3, 114-126. [CrossRef]

28. Reza, B.; Sadiq, R.; Hewage, K. Emergy-based life cycle assessment (Em-LCA) of multi-unit and single-family residential buildings in Canada. Int. J. Sustain. Built Environ. 2014, 3, 207-224. [CrossRef]

29. La Fleur, L.; Rohdin, P.; Moshfegh, B. Energy Renovation versus Demolition and Construction of a New Building-A Comparative Analysis of a Swedish Multi-Family Building. Energies 2019, 12, 2218. [CrossRef]

30. Morelli, M.; Harrestrup, M.; Svendsen, S. Method for a component-based economic optimisation in design of whole building renovation versus demolishing and rebuilding. Energy Policy 2014, 65, 305-314. [CrossRef]

31. Elmezaini, N. Demolition or Restoration: A Case Study. Br. J. Appl. Sci. Technol. 2015, 10, 1-10. [CrossRef]

32. Itard, L.; Klunder, G. Comparing environmental impacts of renovated housing stock with new construction. Build. Res. Inf. 2007, 35, 252-267. [CrossRef]

33. Brown, M.; Ulgiati, S. Emergy-based indices and ratios to evaluate sustainability: Monitoring economies and technology toward environmentally sound innovation. Ecol. Eng. 1997, 9, 51-69. [CrossRef]

34. Odum, H.T. Environmental Accounting: Emergy and Environmental Decision Making; John Wiley: New York, NY, USA, 1996.

35. Brown, M.T.; Ulgiati, S. Energy quality, emergy, and transformity: H.T. Odum's contributions to quantifying and understanding systems. Ecol. Model. 2004, 178, 201-213. [CrossRef]

36. Chen, W.; Liu, W.; Geng, Y.; Brown, M.T.; Gao, C.; Wu, R. Recent progress on emergy research: A bibliometric analysis. Renew. Sustain. Energy Rev. 2017, 73, 1051-1060. [CrossRef]

37. Hau, J.L.; Bakshi, B. Promise and problems of emergy analysis. Ecol. Model. 2004, 178, 215-225. [CrossRef]

38. Reza, B.; Sadiq, R.; Hewage, K. Emergy-based life cycle assessment (Em-LCA) for sustainability appraisal of infrastructure systems: A case study on paved roads. Clean Technol. Environ. Policy 2014, 16, 251-266. [CrossRef]

39. Lee, J.M.; Braham, W.W. Building emergy analysis of Manhattan: Density parameters for high-density and high-rise developments. Ecol. Model. 2017, 363, 157-171. [CrossRef]

40. Pulselli, R.; Simoncini, E.; Bastianoni, S. Emergy analysis of building manufacturing, maintenance and use: Em-building indices to evaluate housing sustainability. Energy Build. 2007, 39, 620-628. [CrossRef]

41. Odum, H.T. Environment, Power, and Society for the Twenty-First Century: The Hierarchy of Energy; Columbia University Press: New York, NY, USA, 2007.

42. Liu, G.; Hao, Y.; Dong, L.; Yang, Z.; Zhang, Y.; Ulgiati, S. An emergy-LCA analysis of municipal solid waste management. Resour. Conserv. Recycl. 2017, 120, 131-143. [CrossRef] 
43. Brown, M.T.; Buranakarn, V. Emergy indices and ratios for sustainable material cycles and recycle options. Resour. Conserv. Recycl. 2003, 38, 1-22. [CrossRef]

44. He, B.-J.; Zhu, J.; Zhao, D.-X.; Gou, Z.; Qi, J.-D.; Wang, J. Co-benefits approach: Opportunities for implementing sponge city and urban heat island mitigation. Land Use Policy 2019, 86, 147-157. [CrossRef]

45. Wang, H.; Dai, H.; Dong, L.; Xie, Y.; Geng, Y.; Yue, Q.; Ma, F.; Wang, J.; Du, T. Co-benefit of carbon mitigation on resource use in China. J. Clean. Prod. 2018, 174, 1096-1113. [CrossRef]

46. Tibrewal, K.; Venkataraman, C. Climate co-benefits of air quality and clean energy policy in India. Nat. Sustain. 2020, 1-9. [CrossRef]

47. Kuylenstierna, J.C.I.; Heaps, C.G.; Ahmed, T.; Vallack, H.W.; Hicks, W.K.; Ashmore, M.R.; Malley, C.S.; Wang, G.; Lefèvre, E.N.; Anenberg, S.C.; et al. Development of the Low Emissions Analysis Platform-Integrated Benefits Calculator (LEAP-IBC) tool to assess air quality and climate co-benefits: Application for Bangladesh. Environ. Int. 2020, 145, 106155. [CrossRef] [PubMed]

48. He, K.; Lei, Y.; Pan, X.; Zhang, Y.; Zhang, Q.; Chen, D. Co-benefits from energy policies in China. Energy 2010, 35, 4265-4272. [CrossRef]

49. Howden-Chapman, P.; Keall, M.; Whitwell, K.; Chapman, R. Evaluating natural experiments to measure the co-benefits of urban policy interventions to reduce carbon emissions in New Zealand. Sci. Total Environ. 2020, 700, 134408. [CrossRef]

50. Chae, Y. Co-benefit analysis of an air quality management plan and greenhouse gas reduction strategies in the Seoul metropolitan area. Environ. Sci. Policy 2010, 13, 205-216. [CrossRef]

51. Dong, H.; Dai, H.; Dong, L.; Fujita, T.; Geng, Y.; Klimont, Z.; Inoue, T.; Bunya, S.; Fujii, M.; Masui, T. Pursuing air pollutant co-benefits of CO 2 mitigation in China: A provincial leveled analysis. Appl. Energy 2015, 144, 165-174. [CrossRef]

52. Younger, M.; Morrow-Almeida, H.R.; Vindigni, S.M.; Dannenberg, A.L. The built environment, climate change, and health: Opportunities for co-benefits. Am. J. Prev. Med. 2008, 35, 517-526. [CrossRef]

53. MacNaughton, P.; Cao, X.; Buonocore, J.; Cedeno-Laurent, J.; Spengler, J.; Bernstein, A.; Allen, J.G. Energy savings, emission reductions, and health co-benefits of the green building movement. J. Expo. Sci. Environ. Epidemiol. 2018, 28, 307-318. [CrossRef]

54. Adele, H.; Carlos, C.S. Health Co-Benefits of Green Building Design Strategies and Community Re-silience to Urban Flooding: A Systematic Review of the Evidence. Int. J. Environ. Res. Public Health 2017, 14, 1519.

55. Eisenstein, W.; Fuertes, G.; Kaam, S.; Seigel, K.; Arens, E.; Mozingo, L. Climate co-benefits of green building standards: Water, waste and transportation. Build. Res. Inf. 2017, 45, 828-844. [CrossRef]

56. Rose, J.; Thomsen, K.E.; Mørck, O.C.; Gutierrez, M.S.M.; Jensen, S. Østergaard Refurbishing blocks of flats to very low or nearly zero energy level-technical and financial results plus co-benefits. Energy Build. 2019, 184, 1-7. [CrossRef]

57. Novikova, A.; Szalay, Z.; Horváth, M.; Becker, J.; Simaku, G.; Csoknyai, T. Assessment of energy-saving potential, associated costs and co-benefits of public buildings in Albania. Energy Effic. 2020, 2020, 1-21. [CrossRef]

58. Ping, J.; Dong, W.; Kung, Y.; Geng, Y. Analysing co-benefits of the energy conservation and carbon reduction in China's large commercial buildings. J. Clean. Prod. 2013, 58, 112-120.

59. Ferreira, M.A.P.S.; De Almeida, M.G.; Rodrigues, A. Impact of co-benefits on the assessment of energy related building renovation with a nearly-zero energy target. Energy Build. 2017, 152, 587-601. [CrossRef]

60. Almeida, M.; Ferreira, M. Cost effective energy and carbon emissions optimization in building reno-vation (Annex 56). Energy Build. 2017, 152, 718-738. [CrossRef]

61. Kumanayake, R.; Luo, H. A tool for assessing life cycle $\mathrm{CO}_{2}$ emissions of buildings in Sri Lanka. Build. Environ. 2018, 128, 272-286. [CrossRef]

62. Li, D.; Cui, P.; Lu, Y. Development of an automated estimator of life-cycle carbon emissions for residential buildings: A case study in Nanjing, China. Habitat Int. 2016, 57, 154-163. [CrossRef]

63. Dodoo, A.; Gustavsson, L.; Sathre, R. Lifecycle carbon implications of conventional and low-energy multi-storey timber building systems. Energy Build. 2014, 82, 194-210. [CrossRef]

64. Andrić, I.; Pina, A.; Ferrão, P.; Lacarrière, B.; Le Corre, O. The impact of renovation measures on building environmental performance: An emergy approach. J. Clean. Prod. 2017, 162, 776-790. [CrossRef]

65. Cheng, B.Y.; Sun, W.G.; Sun, S.Q. Study on the Climatological Calculation Methods of Total Solar Radiation in Chongqing Area. J. Southwest Univ. 2011, 33, 94-104.

66. Lan, S.; Qin, P. Emergy analysis of ecosystems. Ying Yong Sheng Tai Xue Bao = J. Appl. Ecol./Zhongguo Sheng Tai Xue Xue Hui, Zhongguo Ke Xue Yuan Shenyang Ying Yong Sheng Tai Yan Jiu Suo Zhu Ban 2001, 12, 129.

67. Zhang, X.; Wang, F. Assessment of embodied carbon emissions for building construction in China: Comparative case studies using alternative methods. Energy Build. 2016, 130, 330-340. [CrossRef]

68. Peng, C. Calculation of a building's life cycle carbon emissions based on Ecotect and building information modeling. J. Clean. Prod. 2016, 112, 453-465. [CrossRef]

69. Mao, C.; Shen, Q.; Shen, L.; Tang, L. Comparative study of greenhouse gas emissions between off-site prefabrication and con-ventional construction methods: Two case studies of residential projects. Energy Build. 2013, 66, 165-176. [CrossRef]

70. Zhan, J.; Liu, W.; Wu, F.; Li, Z.; Wang, C. Life cycle energy consumption and greenhouse gas emissions of urban residential buildings in Guangzhou city. J. Clean. Prod. 2018, 194, 318-326. [CrossRef]

71. NDRC. The Baseline Emission Factor of China Regional Power Grid in 2016. Available online: https://www.ndrc.gov.cn/hdjl/ yjzq/201704/t20170414_1165985.html (accessed on 12 September 2017). 
72. Wang, L.; Zhang, J. Emergy evaluation of power plant eco-industrial park. Ying Yong Sheng Tai Xue Bao = J. Appl. Ecol. 2004, 15, 1047-1050. [CrossRef]

73. Dodoo, A.; Gustavsson, L.; Le Truong, N. Primary energy benefits of cost-effective energy renovation of a district heated multi-family building under different energy supply systems. Energy 2018, 143, 69-90. [CrossRef]

74. Ascione, F.; Bianco, N.; De Masi, R.F.; Perone, T.; Ruggiero, S.; Strangio, P.; Vanoli, G.P. Light and heavy energy refurbishments of Mediterranean offices. Part II: Cost-optimal energy renovation of an institutional building. In Proceedings of the International High-Performance Built Environment Conference-A Sustainable Built Environment Conference 2016 Series, Sydney, Australia, 17-18 November 2016; Ding, L., Fiorito, F., Osmond, P., Eds.; Elsevier: Amsterdam, The Netherlands, 2017 ; pp. 1518-1530.

75. Pan, W.; Li, K.; Teng, Y. Rethinking system boundaries of the life cycle carbon emissions of buildings. Renew. Sustain. Energy Rev. 2018, 90, 379-390. [CrossRef]

76. Li, D.; Zhu, J.; Hui, E.C.M.; Leung, B.Y.P.; Li, Q. An emergy analysis-based methodology for eco-efficiency evaluation of building manufac-turing. Ecol. Indic. 2011, 11, 1419-1425. [CrossRef]

77. La Fleur, L.; Moshfegh, B.; Rohdin, P. Measured and predicted energy use and indoor climate before and after a major renovation of an apartment building in Sweden. Energy Build. 2017, 146, 98-110. [CrossRef]

78. Chau, C.; Leung, T.; Ng, W. A review on Life Cycle Assessment, Life Cycle Energy Assessment and Life Cycle Carbon Emissions Assessment on buildings. Appl. Energy 2015, 143, 395-413. [CrossRef]

79. Niemelä, T.; Kosonen, R.; Jokisalo, J. Cost-effectiveness of energy performance renovation measures in Finnish brick apartment buildings. Energy Build. 2017, 137, 60-75. [CrossRef]

80. Mateus, R.; Silva, S.M.; Almeida, M. Environmental and cost life cycle analysis of the impact of using solar systems in energy renovation of Southern European single-family buildings. Renew. Energy 2019, 137, 82-92. [CrossRef]

81. Jradi, M.; Veje, C.; Jørgensen, B. Deep energy renovation of the Mærsk office building in Denmark using a holistic design approach. Energy Build. 2017, 151, 306-319. [CrossRef] 